\title{
Resins and gums in historical iatrosophia texts from Cyprus - a botanical and medico-pharmacological approach
}

\author{
Andreas Lardos ${ }^{1}$, José Prieto-Garcia ${ }^{1}$ and Michael Heinrich ${ }^{1,2}$ \\ 1 Centre for Pharmacognosy and Phytotherapy, The School of Pharmacy, University of London, London, UK \\ ${ }^{2}$ Centre for Phytochemistry and Pharmacology, Southern Cross Plant Science, Southern Cross University, Lismore, NSW, Australia
}

Edited by:

Gunter Peter Eckert, Goethe-University of Frankfurt, Germany

Reviewed by:

Michael Adams, University of Basel,

Switzerland

Paula De Vos, San Diego State

University, USA

\section{${ }^{*}$ Correspondence:}

Andreas Lardos, Centre for

Pharmacognosy and Phytotherapy, The

School of Pharmacy, University of

London, 29-39 Brunswick Square,

London WC1N 1AX, UK.

e-mail:andreas.lardos@bluewin.ch
This study explores historical iatrosophia texts from Cyprus from a botanical and medicopharmacological point of view focusing on remedies containing resins and gums. The iatrosophia are a genre of Greek medical literature of Byzantine origin and can be described as medicine handbooks which serve as therapeutic repositories containing recipes or advice. To extract and analyze information on plant usage in such sources - which are largely unedited texts and so far have not been translated - we investigate (i) the relationship of the iatrosophia to Dioscorides' De Materia Medica as well as historic pharmaceutical books or standard texts on modern phytotherapy and (ii) the validity of the remedies by comparing them to modern scientific data on reported biological activities. In the six texts investigated 27 substances incorporating plant exudates are mentioned. They are obtained from over 43 taxa of higher plants and in particular are used to treat dermatological, gastrointestinal, and respiratory tract conditions. The comparison to historic pharmaceutical books and phytotherapy texts reflects the gradual decline of the use of plant exudates in Western medicine. While remarkable parallels to Dioscorides' text exist, the non-Dioscoridean influence suggests a complex pattern of knowledge exchange. Overall, this resulted in an integration of knowledge from so far poorly understood sources. The comparison with bioscientific data reveals a fragmentary picture and highlights the potential of these unexplored substances and their uses. Where relevant bioscientific data are available, we generally found a confirmation. This points to a largely rational use of the associated remedies. Taken together, the iatrosophia are a valuable resource for ethnopharmacological and natural product research. Most importantly they contribute to the understanding of the development of herbal medicines in the (Eastern) Mediterranean and Europe.

Keywords: historical texts, iatrosophia, Cyprus, Eastern Mediterranean, resins, gums

\section{INTRODUCTION}

The present study is part of a larger project which explores the herbal materia medica and its use in historical iatrosophia texts from Cyprus as well as modern herbal knowledge in the island's monasteries where some of these texts were written. The term iatroso-

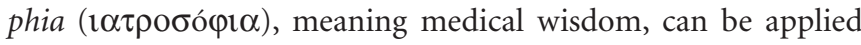
to both orally transmitted medicinal recipes and corresponding medical texts in Greek. This study focuses on the textual sources which constitute themselves a special genre of medical literature of Byzantine origin.

Among the many drugs described in these texts, resins, and gums are endowed with a special relevance. Humans have employed resins for very diverse purposes including esthetic, ceremonial, or therapeutic uses but also in arts and industry. As they often belonged to the most sought after materials, they have been traded between the different cultures around the world from the earliest times. Around the middle of the second millennia before the Common Era (CE) trade routes were established which brought resins to the Mediterranean region. Amber from the Baltic region was traded to the Mycenaeans and the Phoenicians brought the material by ship from northern Europe. Frankincense or myrrh was supplied to Egypt from of a place called Punt, which is believed to have lied in the region of Sudan,
Ethiopia, or Somalia (Serpico, 2000, p. 438; Langenheim, 2003, pp. 257-267). In the following centuries the incense road leading from the south-coast of the Arabian Peninsula northwards to the Mediterranean coast was established and by $500 \mathrm{BCE}$ a substantial trade existed with the ancient Greek world (Langenheim, 2003, pp. 283-287). Resins were not only brought to the Mediterranean but the region itself is notable for a number of resin producing trees, shrubs, or herbs (Howes, 1950). Pedanius Dioscorides (first

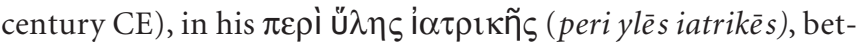
ter known by its Latin title De Materia Medica, mentioned that styrax, mastic, scammony, various coniferous resins, as well as ladanum and resin of the terebinth could be obtained from places in the Eastern Mediterranean. For the latter two he particularly noted Cyprus as provenance (Berendes, 1902; Chrysanthis, 1942). Archeological excavations at Pyrgos-Mavrorachi, a metallurgic Bronze age site near the south-coast of the island dated to the nineteenth century BCE brought several relicts of plant exudates to light, some of them were identified as pine or terebinth resins (Lentini, 2004, cited in Hadjikyriakou, 2007, pp. 50, 154-55). A Mycenaean tablet of the same era mentioned a substance called ki-ta-no, now interpreted as terebinth resin which appears to have been imported to Crete from Cyprus or Syria (Karageorghis, 1996, p. 66). 
We previously investigated the species contained in a iatrosophia text from Cyprus (Lardos, 2006). The fact that quite a number of plant exudates were mentioned in this text together with the absence of published studies which discuss this specific class of natural products in the context of historical medical texts has prompted us to undertake the present study. Here we apply a special procedure for unlocking information on species and their uses in up to now non-translated and largely unedited iatrosophia texts. Based on the classification of medicinal uses into greater categories we highlight similarities and differences between the iatrosophia and (i) Dioscorides' De Materia Medica, (ii) historic pharmaceutical books from the era when plant drugs were still included in mainstream medicine, and (iii) authoritative texts of modern phytotherapy which serve as scientific standards of herbal medicinal products in Europe. By implementing specific points of the protocol for analyzing historical texts by Buenz et al. (2004) we attempt to examine the validity of the medicinal uses mentioned in the texts by comparing them with reported bioactivity data and at the same time identify previously unexplored cases.

\section{IATROSOPHIA TEXTS}

Many earlier historians showed little enthusiasm for the iatrosophia, considering them as "diluted and clouded extraction of ancient knowledge with all sorts of superstitious ingredients and invocations" (e.g., Bloch, 1902, p. 512). As commonly understood today, these texts developed in the context of Byzantine hospitals where they served as handbooks for the daily medical practice containing recipes and therapeutic advice (Varella, 1999, p. 579; Touwaide, 2007, pp. 160-161). They can best be described as therapeutic compendia, which contain extracts from classical or Byzantine sources and which often were reproduced on previous compilations (Touwaide, 2007, p. 149). Earliest examples might reach back to the tenth century CE but they certainly became abundant from the fifteenth century onwards (Touwaide, 2007,p. 149; Zisper, 2009, p. 9). After the end of the Byzantine Empire (1453) hospitals of the Byzantine tradition were restricted to Greek orthodox monasteries spread over many parts of the previous empire or to monastic foundations in great cities now part of Greece or Turkey. The tradition of the iatrosophia continued in these monasteries but also in the secular environment among the Greek-speaking population of the Ottoman Empire. The examples produced in this era had a marked influence on the medicine of this group of population (Varella, 1999, pp. 579-583). As illustrated by the text of a traditional healer from Crete or the one from a monastery in Cyprus this tradition was continued until the first decades of the twentieth century (Clark, 2002, p. 339; Lardos, 2006).

The existing literary sources available for the compilation of the first iatrosophia texts included the healing lore of Greek and Roman antiquity and the earlier Byzantine time. Such a list would probably include the Hippocratic texts, Dioscorides, and Galen. Perhaps of greater importance were the Byzantine authors like Oribasius, Aetios of Amida, Alexander of Tralles and Paulus Aegineta. They wrote between the fourth and seventh century CE (Scarborough, 1984, pp. 213, 221-229). By consulting the works of contemporary scholars the writers of the iatrosophia might also have included elements of Arabic/Islamic medicine. Islamic medicine, which had hitherto borrowed from Byzantium exerted a marked influence on
Byzantine therapeutic practice from the tenth century CE onwards and especially between the thirteenth and fourteenth century CE (Varella, 1995; Bennett, 2000; Touwaide, 2007, pp. 163-164). The writers of the hospital and medical craft texts (virtually the iatrosophia) distilled what they found useful from the available sources and supplemented it with new information. Brevity as well as easy access to reliable recipes and recorded practical experience from the bedside was what counted most for them (Bennett, 2000, pp. 280-281; Touwaide, 2007, pp. 150-154, 160-161). As Clark (2002, p. 358 ) could demonstrate by investigating a iatrosophion from Crete - written in 1930 - a commitment to preserve the past combined with the capacity to adapt to changed conditions and incorporate new learning are inherent qualities of this tradition.

Today, several iatrosophia texts have survived in monasteries or private collections in Greece or Cyprus (Varella, 1999, p. 580; Lardos, unpublished results). Individual manuscripts are also stored in public libraries for example in London, Oxford, Paris, and Vienna (Touwaide, 2007, p. 156; Zisper, 2009, pp. 14-27). In a survey including roughly 700 Greek medical manuscripts produced during the Ottoman era it was found that $45 \%$ of them belong to this category (Varella, 1999, p. 578). The lack of existing inventories and difficulties in identifying corresponding texts in the bulk of medical manuscripts are major points which hampered the study of the iatrosophia in the past. To counteract this drawback Touwaide (1992, p. 75) has launched a research program to establish a computerized inventory of all Greek medical manuscripts currently known in library collections (Touwaide, 2007, pp. 156-157).

\section{HISTORICAL TEXTS FROM THE MEDITERRANEAN AS AN ETHNOPHARMACOLOGICAL RESEARCH TOOL}

With the ongoing socio-structural changes in the societies of the Mediterranean region local, mainly orally transmitted knowledge about the uses of plants as medicine and food appears to be declining. It has been demonstrated that in this area information on the local use of plants is increasingly restricted to people of middle age or beyond (Nebel et al., 2006; Gonzalez-Tejero et al., 2008). The consequence of the generational shift with the associated loss of knowledge has forced researchers to emphasize the importance to gather endangered knowledge but also to define creative ways how to reintroduce this knowledge to younger generations of the local societies (Nebel et al., 2006; Hadjichambis et al., 2008). While the loss of pre-existing knowledge seems to be unavoidable to some extent, other perspectives to access information on plant use have opened up. Historical texts from the various medical traditions in and around the Mediterranean basin have become established as a rewarding tool for ethnobotanical or ethnopharmacological research. A number of studies have been published recently which analyzed and contextualized the content of written sources from this area (Lardos, 2006; López-Muñoz et al., 2006; Pardo-de-Santayana et al., 2006; Touwaide, 2007, pp. 168-173; Lev and Amar, 2008; Pollio et al., 2008; Leonti et al., 2009; De-Vos, 2010; Leonti et al., 2010). Historical texts can also provide a unique gateway to discover new medicinal agents. One prominent example to illustrate the role such texts could play in this respect is Gerard's "Herball" (see, e.g., Buenz et al., 2004; Cordell and Colvard, 2005). Since its publication in Britain at the end of the sixteenth century, eighteen different pharmaceuticals were developed from plants that are described in 
this source and 16 of those became approved drugs (Cox, 1998). It has been argued that a careful and systematic re-examination of medicinal plants mentioned historical texts provides an invaluable source for the development of new drugs (Holland, 1994; Riddle, 1996, 2002; Buenz et al., 2004; Fiore et al., 2005). Recent studies were able to corroborate many of the plant uses in historical texts with reported biological activities or identify promising candidates for the development of new drugs (Buenz et al., 2005; Adams et al., 2009, 2011). The previously unexplored atun tree (Atuna racemosa Raf., Chrysobalanaceae) from Samoa which had been identified as candidate in the text analysis of Rumphius's Ambonese Herbal in fact exhibited a pharmacological activity that corresponded to the historical use (Buenz et al., 2006).

\section{CLASSIFICATION AND PROPERTIES OF RESINS AND GUMS}

To define resins and to group them various concepts representing different scientific approaches and disciplines have been suggested. Based on the fact that resins usually are intermixed with other exudates three groups are commonly recognized: resins, balsams, and gum resins (Wolff-Berlin, 1928, p. 50). Resins dissolved in volatile oils are generally called balsams. However, for some researchers balsams are a type of oleo resins restricted to phenolic resins mainly composed of benzoic or cinnamic acids and their esters. Resins mixed with polysaccharides are called gum resins or oleo gum resins if they additionally contain volatile oils (Howes, 1950; Berger, 1964, pp. 1-3; Bruneton, 1995, p. 224). All these resinous exudates can also be classed by the main chemical components of the fraction that is soluble in organic solvents. In doing so, two main groups can be distinguished, terpenoid and phenolic resins. Terpenoid resins predominantly contain mono- or sesquiterpenes in their volatile and di- and triterpenes in their non-volatile fraction while in phenolic resin phenylpropanoids or lipophilic flavonoids are the major groups of compounds. Additionally several mixed resins are known or such which do not fit in these categories (Langenheim, 2003, pp 23-44, 306, 341, 412).

As a consequence of this phytochemical diversity, gums, and resins have often been confused and both terms are used rather loosely (Hepper, 1987; Langenheim, 2003, pp. 23-24, 45). Exudate gums are amorphous solids which basically consist of mixtures of polysaccharides (Boer and Ella, 2000, p. 15). They are readily distinguished from resins and products of a rubbery nature by the fact that they are miscible with water but insoluble in organic solvents (Howes, 1949, p. 5). Depending on their solubility properties in water true gums can be divided in soluble, insoluble and half soluble or semi-insoluble gums (Howes, 1949, p. 5; Mantell, 1949).

Most resins are obtained by tapping or applying incisions to the bark of trees or shrubs. The exudate is collected either when still fluid or in a solid state after the more volatile compounds have evaporated. Such harvesting methods are dramatic interventions for the plant organism and can lead to its debilitation. Moreover, the industrial exploitation of wild populations of resin or gum producing species raises concerns in terms of biodiversity. For example, Pistacia atlantica trees from which fruits are collected to extract terebinth oil should not be tapped since this would have a negative impact on the fruit production (Panaretos, 1979). Because of the recent overexploitation of agar wood several Aquilaria species are threatened with extinction, as a consequence all Thymelaeaceae known as a source for the material have now been classified into the CITES Appendix II (Ito and Honda, 2005). As illustrated by Langenheim (2003, p. 466) at the example of resin use in tropical ecosystems, the challenge, here too, is to develop "a balance of economic success and sustainable management."

\section{MATERIALS AND METHODS SEARCH FOR IATROSOPHIA TEXTS}

This study involves six iatrosophia texts (Table 1) to which we have gained access through a hand-search in various libraries in Cyprus and the United Kingdom as well as in the 21 monasteries taking part in the ethnobotanical field study in Cyprus as part of the overall project. Most of the texts seem to have been in circulation on the island during the Ottoman (1571-1878) and British era (18781960) (Kargotis, 1951; Chrysanthis, 1966). They were written by monks (IM, GP - see Table 1 for the full names of the texts) and traditional healers (KYP) or stood in connection to some priests (IPM, IPP). While two of the six (IM, KYP) were demonstrably produced in Cyprus, the status of further three (IPM, IPP, KI) is ambiguous in this respect. The Geoponikon (GP) from Agapios Landos originates from Crete but printed copies of the manuscript were produced in Venice as early as 1643 (Kostoula, 1991) and distributed in Cyprus in the following centuries (Spanopoulos, 1935, p. 53; Georgiadis, 1995, p. 134). In all but one case (KYP) the texts could be accessed using print editions of the original manuscript.

Table 1 |The six investigated iatrosophia texts.

\begin{tabular}{|c|c|c|c|}
\hline $\begin{array}{l}\text { Text- } \\
\text { code }\end{array}$ & $\begin{array}{l}\text { Original manuscript } \\
\text { Title } \\
\text { Author (year), } \\
\text { Place of origin }\end{array}$ & $\begin{array}{l}\text { Working copy } \\
\text { Text type } \\
\text { Editor (year), } \\
\text { Place }\end{array}$ & Rec. $^{b}$ \\
\hline GP & $\begin{array}{l}\text { Geoponikon } \\
\text { Agapios Landos (1585-1656) } \\
\text { Crete GR, edit. Venice, 1643 }\end{array}$ & $\begin{array}{l}\text { Print edition } \\
\text { D. D. Kostoula (1991), } \\
\text { Volos GR }\end{array}$ & $\begin{array}{l}143 \\
+64^{*}\end{array}$ \\
\hline IM & $\begin{array}{l}\text { latrosophikon Antidotarion } \\
\text { Mitrophanous (1790-1867) } \\
\text { Mon. of Makhairas CY, } 1849\end{array}$ & $\begin{array}{l}\text { Print edition } \\
\text { Filaretos (1924), } \\
\text { Makhairas CY }\end{array}$ & 493 \\
\hline IPM & $\begin{array}{l}\text { latrosophi tou Papa Michailli } \\
\text { ? Michaillis } \\
\text { ? Vasa (Koilani) CY, undated }\end{array}$ & $\begin{array}{l}\text { Print edition } \\
\text { G. Petridis (2000), } \\
\text { Limassol CY }\end{array}$ & 39 \\
\hline IPP & $\begin{array}{l}\text { latrosophikon Papa tis Petras } \\
\text { Anonymous } \\
\text { ? Petra CY, ca. eighteenth century }\end{array}$ & $\begin{array}{l}\text { Print edition } \\
\text { G. I. Spanopoulos (1935), } \\
\text { Nicosia CY }\end{array}$ & 13 \\
\hline $\mathrm{KI}$ & $\begin{array}{l}\text { Ena Kypriako latrosophi } \\
\text { Anonymous } \\
\text { ? CY, undated }\end{array}$ & $\begin{array}{l}\text { Print edition } \\
\text { K. Chrysanthis (1951), } \\
\text { Nicosia CY }\end{array}$ & 67 \\
\hline KYP & $\begin{array}{l}\text { Kyprianarion } \\
\text { Velephantou (1913), } \\
\text { Lefkosia (Nicosia) CY }\end{array}$ & $\begin{array}{l}\text { Manuscript (copy) } \\
\text { Anonymous (1978), } \\
\text { Athens GR }\end{array}$ & 24 \\
\hline
\end{tabular}

Total number of recipes containing plants as ingredients

a See reference list for full citations.

${ }^{b}$ Counted number of recipes which contain plants as ingredients and which are destined for use in humans.

* In addition to the 143 recipes, 64 chapters dealing with plants and their virtues were counted. 


\section{PROTOCOL FOR THE ANALYSIS OF IATROSOPHIA TEXTS}

For analyzing the texts a multi-step protocol was developed (Figure 1). In steps 1 and 2 information about the use of plants was extracted and itemized according to recipe or chapter, substance name, part used, mode of preparation, way of application, and use. Every mentioning of a substance in one of the texts was entered in the database as a separate record (the term "substance" is used as a substitution for both plant and plant part or product in the consecutive text). The resulting inventory provided the base for the second part of the protocol (steps 3-6) which involved the selection of a specific substance class, the identification of the species and the categorization of the uses. The third part of the protocol involved the investigation from a medicinal and pharmacological point of view (steps 7-10).

\section{Extraction and translation (steps 1 and 2)}

The information was extracted by reading through the entire text. All the texts were written in the vernacular Greek of the respective time, some of them with a Cypriot-Greek coloring. The language is relatively well comprehensible to a reader with knowledge of Modern Greek. When required, specific dictionaries, etymological lexica (Hadjiioannou, 2000; Papangellou, 2001), or glossaries (Myrianthopoulos, 1925; Kostoula, 1991) were consulted. The disorders or symptoms that were mentioned in a recipe were first translated using popular medicinal and medicinal literature or glossaries dealing with the topic of the local nomenclature of diseases (Myrianthopoulos, 1925; Kyriazis, 1926; Chrysanthis, 1944, 1988; Kyprianou, 1987). Ancient names of conditions were cross-checked with their correspondents in the "Deutsches Krankheitsnamen-Buch” (Höfler, 1899).Complementary information

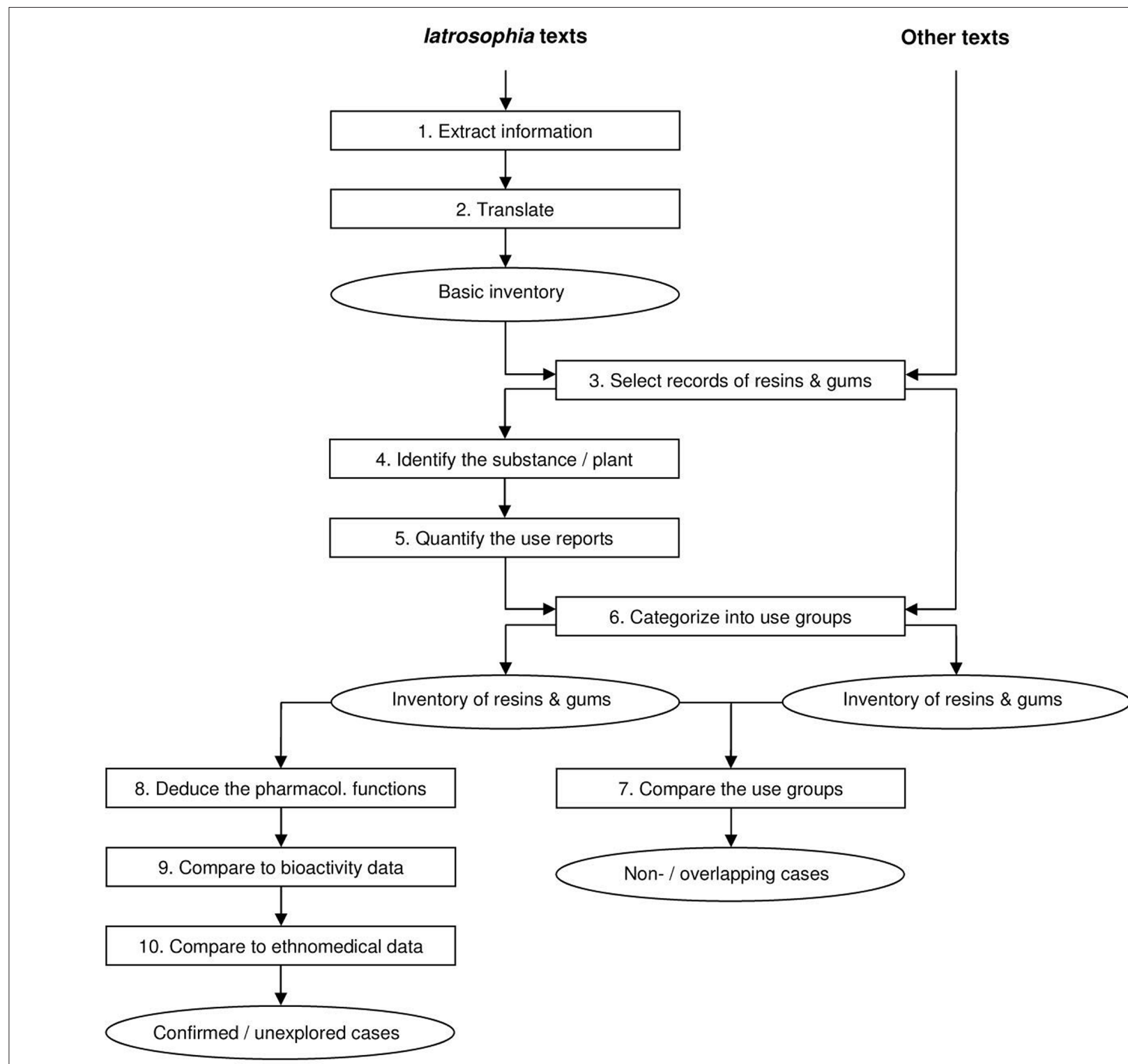

FIGURE 1 | Flowchart of the 10 steps in the analysis of the iatrosophia texts. Steps 3 and 6 were also applied on other texts (i.e., Dioscorides' De Materia Medica, historic pharmaceutical books and standard texts of modern phytotherapy) and served to establish a separate inventory of resins and gums of their owns. 
including the general medical situation and the diseases prevalent on the island at that time was drawn from books on the local history of medicine (Koureas, 2006; Marangou and Georgiadis, 2006; Stavridis, 2006). Particular care was taken to retain the original wording of a use mentioned in a text. The translated use was then cross-checked with a German edition of "Harrison's principles of internal medicine" (Dietel et al., 2003) or "Health Topics" of the Medline Plus database ${ }^{1}$ and if required transcribed into the appropriate clinical term. To accomplish this, a clear understanding of the mentioned condition was essential. However, many of the medicinal uses were ambiguous and sometimes difficult to link to a particular clinical term. For example, the condition "wound on the leg that opens again and again out of its own" can be interpreted as a chronic wound perhaps associated with infection and inflammation or more specifically a venous ulcer.

Selection of records and identification of the substances (steps 3 and 4) From the established basic inventory records referring to resin and gum exudates were selected. These also included related products such as volatile oil separated through distillation of the resin or wood tar which usually was obtained through a dry distillation by burning resinous wood in an oven (Blaschek et al., 2007).

By applying linguistic and pharmacognostic criteria a substance was first identified on the basis of the substance name and then assigned to the appropriate botanical source. To establish the identity of a substance the iatrosophia name was cross-referenced with plant or substance names listed in:

(i) Historical texts including De Materia Medica of Dioscorides (Berendes, 1902; Wellmann, 1906/1907/1914) and the "Medical Compendium in Seven Books" of Paulus Aegineta (Adams, 1844/1846/1847; Heiberg, 1921/1924). They were available in Ancient Greek as digitized texts from TLG (Thesaurus Linguae Graecae), University of California, Irvine and in English or German translations as scanned books including also commentaries about the identity of drugs and their sources. Berendes' (1902) German translation of Dioscorides was accessed via the online catalog of Heilpflanzen-Welt (multi MED vision GbR) and Adams' (1844/1846/1847) English translation of Paulus Aegineta downloaded as PDF file from Bibliothèque Interuniversitaire de Medicine et d'Odontologie, Paris. In addition appropriate publications on the materia medica of historical texts of ancient Greek, Byzantine, medieval Arabic/Islamic, and Ottoman origin which listed original names were consulted (Langkavel, 1866; Tschirch and Lippmann, 1933; Riddle, 1987; Varella, 1995; Aliotta et al., 2003; Lev and Amar, 2008; Ölker and Direkçi, 2009).

(ii) Lexica, glossaries, etymological keys, and botanical literature containing beside Greek also Cypriot-Greek or Turkish names (Gennadios, 1914; Myrianthopoulos, 1925; Panaretos, 1967; Kostoula, 1991; Viney, 1994; Hadjiioannou, 2000; Papangellou, 2001; Hadjikyriakou, 2007).

(iii) Miscellaneous references including popular medicinal, pharmaco-historical, and ethnobotanical literature as well as dictionaries of the Greek or Turkish language (for all references see Table 2).

'http://www.nlm.nih.gov/medlineplus/
After the identity had been established the substance was assigned to the appropriate botanical source based on the information in up-to-date or if necessary also earlier pharmacognostic reference books (Richter, 1827; Tschirch and Stock, 1935/1936; Howes, 1949; Berger, 1964; List et al., 1972; Langenheim, 2003; Blaschek et al., 2007; Nussinovitch, 2010) and other scientific literature. In cases where the respective species can be found in Cyprus this was done using the "Flora of Cyprus" (Meikle, 1977/1985) or other botanical literature on the local flora (Della, 1999; Tsintides et al., 2002; Hadjikyriakou, 2007). All references were cross-checked. Scientific plant names were checked with the Tropicos, Missouri Botanical Garden ${ }^{2}$, or International Plant Name Index ${ }^{3}$.

\section{Quantification and categorization of the use reports into use groups (steps 5 and 6)}

Following the approach of Kufer et al. (2005) every use of a substance mentioned in one of the texts was counted as one use report (UR). Records referring to identical uses of a substance within the same text were considered duplicates and removed from the list. Finally, every medicinal use was categorized into 1 of the 12 pre-established medicinal use groups (UGs) largely based on body systems: CA Cardiovascular and blood, EE - Ears and eyes, DE - Dermatological, FV - Fevers (including malaria), GI - Gastrointesinal and hepatic, GY - Gynecological, HA - Headache and migraine, MS - Musculosceletal, OC - Oral cavity, RE - Respiratory tract, UG - Urogenital, VA - Various conditions.

\section{Comparison to uses mentioned in other texts (step 7)}

To reveal similarities of the use pattern of a substance, a comparison was conducted between the UGs treated by the uses mentioned in iatrosophia and those mentioned in: (i) Berendes' (1902) German translation of De Materia Medica of Dioscorides; (ii) Western pharmaceutical books from the era before plant drugs were largely abandoned from mainstream medicine including British Pharmaceutical Codex, 2nd Edition (Council of the Pharmaceutical Society of Great Britain, 1911) and United States Dispensatory (Remington and Woods, 1918). They both were accessed via the online catalog of Henriette's Herbal Homepage; (iii) Authoritative standard texts of phytotherapy in Europe including German Commission E Monographs (BGA, 1978-1994), British Herbal Compendium, Volume 1 (Bradley, 1992), Potter's Herbal Cyclopedia (Williamson, 2003), Hagers Enzyklopädie der Arzneistoffe und Drogen (Blaschek et al., 2007) and ESCOP monographs (ESCOP, 2009). For this purpose, every medicinal use of a substance mentioned in these references was categorized into one of the 12 UGs [see Quantification and Categorization of the use Reports into Use Groups (Steps 5 and 6)]. For each substance the established UGs were then juxtaposed to those in iatrosophia and evaluated based on the number of UGs of the substances the compared texts had in common.

\section{Comparison to reported bioactivity data (step 8 and 9)}

To enable a one-to-one association between the substance and the mentioned use the detailed comparison to reported bioactivity data was conducted involving only simple remedies. These are remedies that include only one active substance, as opposed to compound

\footnotetext{
${ }^{2}$ http://www.tropicos.org/

${ }^{3}$ www.ipni.org
} 
Table 2 | Identification of the substance names mentioned in the iatrosophia.

\begin{tabular}{|c|c|c|c|c|}
\hline Name in iatrosophia & Correspondent name ${ }^{b}$ & Cent. $^{c}$ & Reference $^{d}$ & Substance ${ }^{e}$ \\
\hline \multirow{3}{*}{ bouchoúr yiági } & bouchoúri yag & 19 & Hanbury (1857) & \\
\hline & bukhur yaghy & 19 & Hanbury (1857) & \\
\hline & bohur & 20 & Viney (1994, p. 250) & \\
\hline \multirow[t]{6}{*}{ katráni, katrán } & qatrân & 10 & Tschirch and Lippmann (1933, p. 1361) & (1) Cedar tar \\
\hline & katran & $\leq 19$ & Lev (2002) & \\
\hline & katran & 21 & Lev and Amar (2002) & \\
\hline & qitrân & $11-13$ & Lev and Amar (2008, p. 497) & (2) Pine tar \\
\hline & kara katran & 21 & Sezik et al. (2001) & \\
\hline & katrámi, katrás & $\leq 20$ & Gennadios (1914, p.782) & (3) Wood tar (of conifers) \\
\hline kechripárin, chechripárin & kechrimpári & 21 & Webster's Online Dictionary ${ }^{d}$ & \\
\hline kechriparóladon & kechrimpári // ládi, -ládo & 21 & Webster's Online Dictionary ${ }^{d}$ & Amber oil \\
\hline \multirow{3}{*}{$\begin{array}{l}\text { kómmi arapikón, kómmi } \\
\text { aravikón }\end{array}$} & komidè arapikōn & $03-13$ & Langkavel (1866, p. 1.2) & Gum arabic \\
\hline & kómmi aravikón & $\leq 20$ & Gennadios (1914, p. 28) & \\
\hline & aravikó kómmi & 21 & Webster's Online Dictionary ${ }^{d}$ & \\
\hline \multirow[t]{2}{*}{ kommídi } & $\begin{array}{l}\text { kommi [...] amygdalēs, } \\
\text {-kerasōn, -tes kokkomyleas }\end{array}$ & 01 & $\begin{array}{l}\text { Berendes }(1902,1.157,174,176), \text { Wellmann } \\
(1906 / 1907 / 1914,1.113,121,123)\end{array}$ & $\begin{array}{l}\text { Gum of various Prunus species } \\
\text { such as almond, cherry, plum }\end{array}$ \\
\hline & $\begin{array}{l}\text { kerasia [...] kommi, } \\
\text { kokkymēleas [...] kommi }\end{array}$ & 07 & $\begin{array}{l}\text { Adams (1844/1846/1847, 7.3, 167, 180), } \\
\text { Heiberg (1921/1924, 7.3.21) }\end{array}$ & \\
\hline \multirow{2}{*}{$\begin{array}{l}\text { kommídi tis kerasiás, komídi } \\
\text { (=píssa) tis kkerashiás }\end{array}$} & kérasos [...] kommi & $\leq 20$ & Gennadios (1914, p. 492) & \\
\hline & $\begin{array}{l}\text { komídin [...] tis keraséas, } \\
\text { píssa tis keraséas }\end{array}$ & $\leq 20$ & Myrianthopoulos (1925) & \\
\hline \multirow[t]{4}{*}{$\begin{array}{l}\text { komídi (kolitsána) tou } \\
\text { moúsklou kai tou damaskínou }\end{array}$} & kommi tēs kokkomyleas & 01 & $\begin{array}{l}\text { Berendes }(1902,1.157,174,176), \text { Wellmann } \\
(1906 / 1907 / 1914,1.113,121,123)\end{array}$ & Plum gum \\
\hline & kokkymēleas [...] kommi & 07 & $\begin{array}{l}\text { Adams }(1844 / 1846 / 1847,7.3,180), \text { Heiberg } \\
(1921 / 1924,7.3 .21)\end{array}$ & \\
\hline & moúskla (kokomílo) & $\leq 20$ & Kostoula (1991) & \\
\hline & damáskino & 21 & Webster's Online Dictionary ${ }^{d}$ & \\
\hline \multirow[t]{4}{*}{ ládanon } & lèdanon, ladanon & $\begin{array}{l}\leq 02 \\
B C E\end{array}$ & $\begin{array}{l}\text { Arnold-Apostolides (1985, p. 396); Riddle } \\
(1987, \text { p. 59) }\end{array}$ & Ladanum \\
\hline & ladanon & 01 & $\begin{array}{l}\text { Berendes }(1902,1.128), \text { Wellmann } \\
(1906 / 1907 / 1914,1.97)\end{array}$ & \\
\hline & ladanon & 07 & $\begin{array}{l}\text { Aliotta et al., }(2003, \text { p. 7.3, 208), Heiberg } \\
(1921 / 1924,7.3 .11)\end{array}$ & \\
\hline & ládanon & $\leq 20$ & Gennadios (1914, p. 512) & \\
\hline
\end{tabular}


Table 2 | Continued

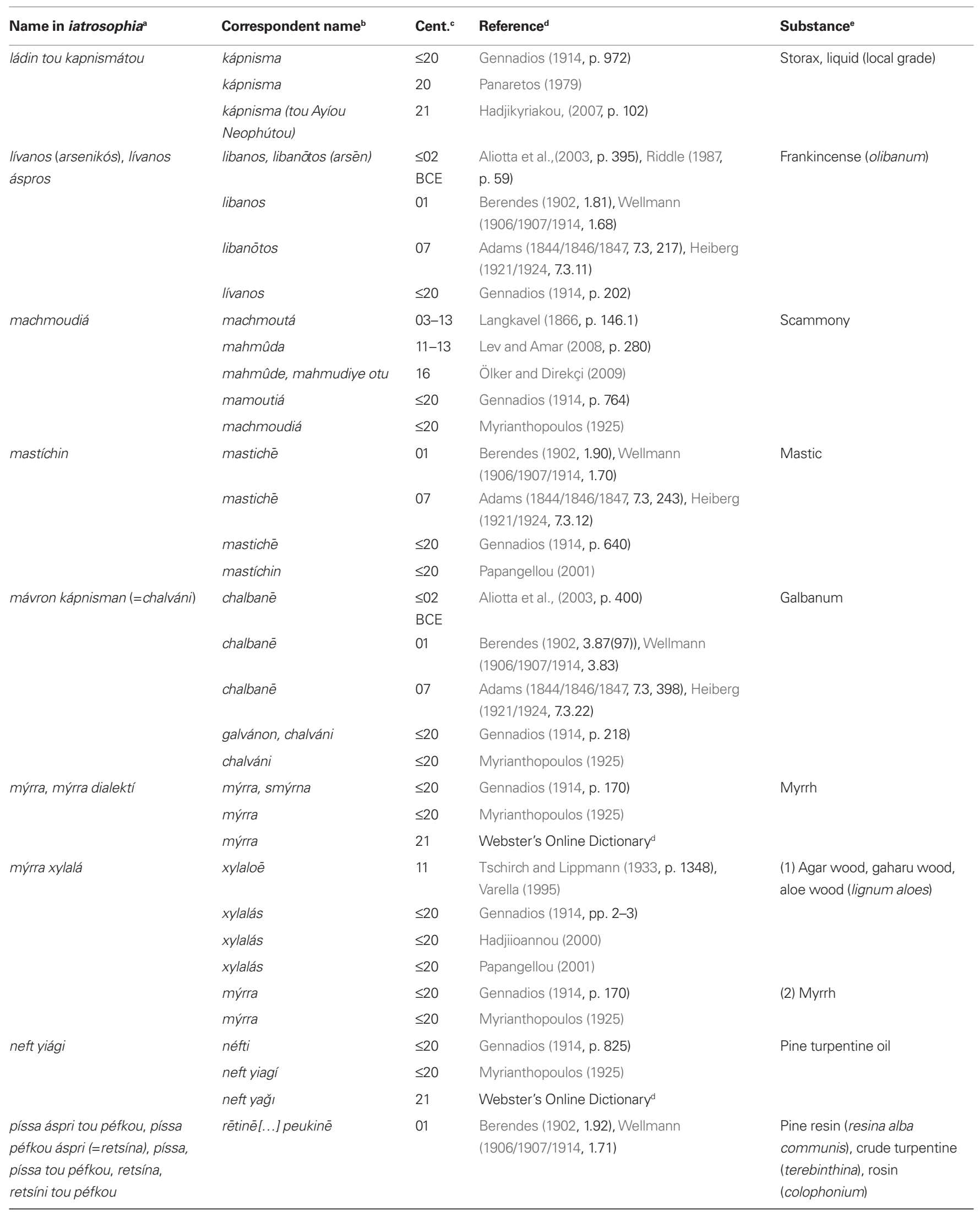


Table 2 | Continued

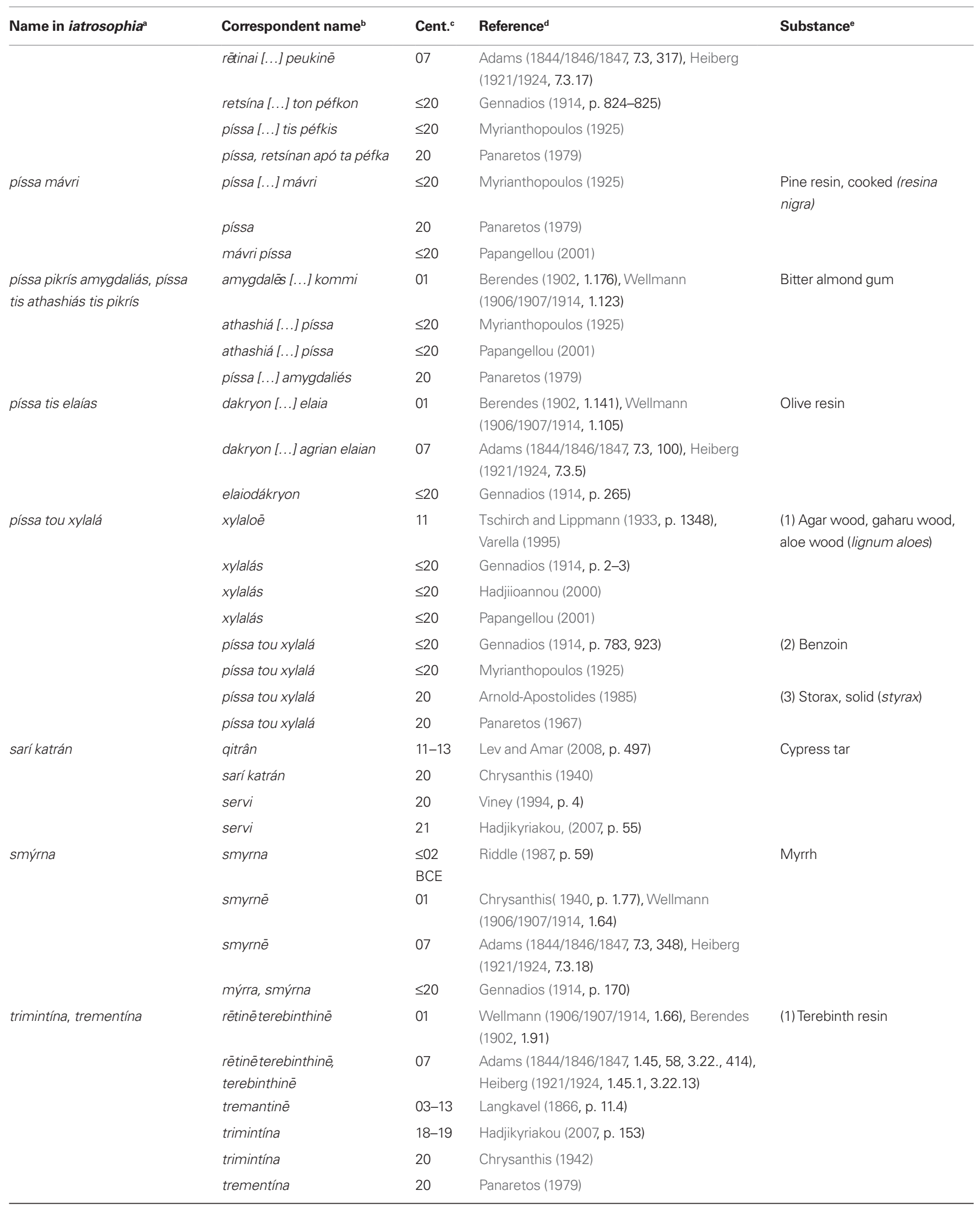


Table 2 | Continued

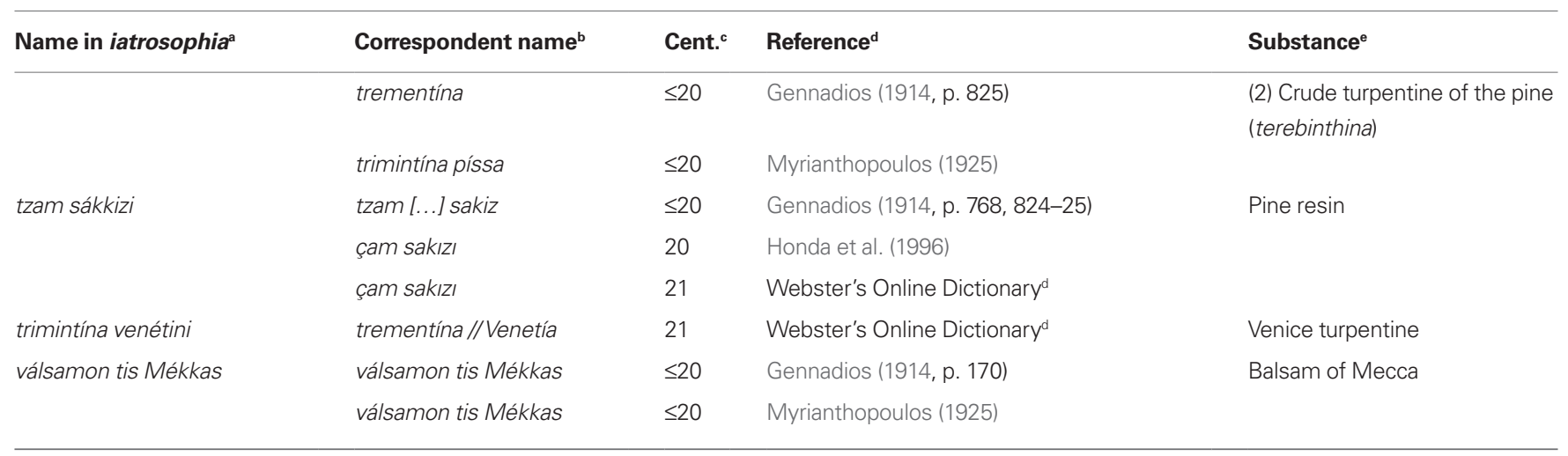

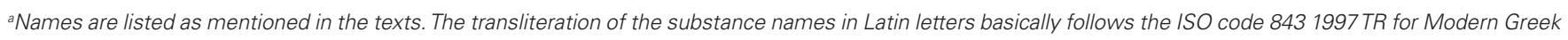

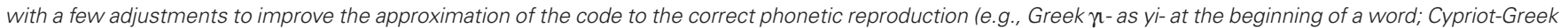
$-\sigma 1 \alpha$ as - sha).

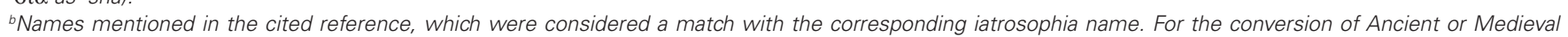

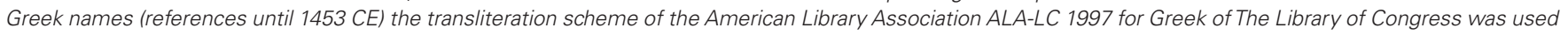
[http://www.loc.gov/catdir/cpso/roman.html (accessed December 03, 2010)].

${ }^{c}$ Century, -ies (CE) from which the correspondent name is documented based on the cited references. Cases referring to BCE are specified.

${ }^{\mathrm{h}} \mathrm{http}$ ://websters-online-dictionary.org/

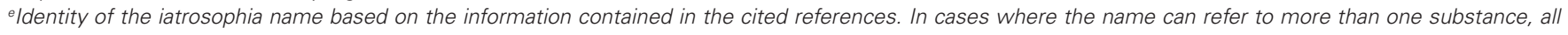
possible interpretations are separately listed and indicated with individual numbers (e.g., 1, 2, 3).

remedies which contain two or more of them. The method was adopted from the protocol for analyzing historical texts introduced by Buenz et al. $(2004,2005)$ and included two basic steps, the extrapolation of the pharmacological functions of a substance and the cross-referencing to reported bioactivity data. In a first step the pharmacological therapy required for the treatment of the respective condition was looked up in "Goodman and Gilman's pharmacological basis of therapeutics" (Brunton et al., 2006) or "Health Topics" of the Medline Plus database $e^{4}$. The pharmacological properties of the suggested therapy were deduced or, if specified, directly adopted and assigned to the respective substance as presumable pharmacological functions. In doing so, we relatively strictly adhered to the information stated in these references and at the same time disregarded less common causes of a respective disease. The procedure is illustrated by the following example: According to recipe GP PMH 05 crude gum Arabic should be eaten to stop the "flux of the belly," which according to Höfler (1899, p. 29, "Bauchfluss") is diarrhea. Most cases of diarrhea are caused by a disturbed intestinal water and electrolyte balance or altered intestinal motility, a medical intervention would include liquid- and electrolyte replacement, bulk-forming agents, motility, or secretory inhibitors. Diarrhea can also be associated with inflammatory bowel disease or microbial infection (Brunton et al., 2006). Assuming that gum Arabic would in fact be able to influence diarrhea bulk-forming, antimotility, antisecretory, anti-inflammatory, or antibiotic effects are likely to be involved in its action. Next, the Web of Knowledge (ISI Web of Knowledge Service for UK Education, Thomson Reuters) and EMBASE (Elsevier Science Publishers) were surveyed for bioactivity data of the respective substance using flexible combinations of substance or species name together with the deduced pharmacological functions as search words. The reported activities were then compared with the associated pharmacological functions and cross-referenced.

${ }^{4} \mathrm{http} / / /$ www.nlm.nih.gov/medlineplus/

\section{Comparison to ethnomedical information (step 10)}

The simple remedies in iatrosophia were compared to De Materia Medica of Dioscorides (Berendes, 1902) and "Medical Compendium in Seven Books" of Paulus Aegineta (Adams, 1844/1846/1847). Dioscorides had a distinct influence on the development of the medicinal knowledge in areas from northern Europe to the Indian Ocean (Riddle, 1985, p. xvii). Paulus Aegineta's early Byzantine work is a "distillation of classical drug theory which captured the essence" (Scarborough, 1984, p. 229). As he wrote before the emergence of Arabic/Islamic medicine an influence on his work from this side could be excluded.

\section{RESULTS AND DISCUSSION IDENTITY OF THE SUBSTANCES AND THEIR BOTANICAL SOURCES}

The identification of plant exudates mentioned in historical texts is notoriously difficult. Before determining the botanical source the substance itself has to be identified by referencing to names cited in the literature. For this purpose we also consulted annotated historical texts. However, several problems remain in terms of the identification of plants mentioned in ancient texts (Piomelli and Pollio, 1994). As highlighted by Riddle (1985, p.xxv), the various authorities who sought to identify the plants mentioned in Dioscorides' De Materia Medica do not always agree and there are real possibilities for error. Dawkins (1936) was of the opinion that ancient plant names can only be interpreted with certain vagueness and Raven et al. (2000) additionally highlighted the unreliability of some identifications in authoritative dictionaries of ancient Greek plant names.

We were in the comfortable situation that the majority of the over 40 substance names of resins, gums, and related products encountered in the iatrosophia (Table 2) were common names which are still known today. In only two cases either no entirely matching (mýrra xylalá - myrrh or agar wood) or only one correspondent name (sarí katrán - cypress tar) could be found in the literature and this leaves the established identity particularly 
uncertain. However, in the majority of the other cases at least three correspondents in Greek, Turkish, and sometimes Arabic were found enabling a straightforward attribution to a defined substance. They included Cypriot-Greek vernacular names (e.g., píssa tis athashiás tis pikrís - bitter almond gum) and trade names (e.g., válsamon tis Mékkas - balsam of Mecca) or such that can be traced far back in history, sometimes for two millennia or more (e.g., lívanos - frankincense, ládanon - ladanum, mastíchin mastic). Assuming that over the centuries the name has not been applied to different herbal drugs, this demonstrates a remarkable continuity of the popular plant nomenclature of the respective cases. Sibthorp was surprised when locals he met on his botanical excursions to Greece in 1787 used the nomenclature of Dioscorides and Theophrastus to name the plants (Bruce, 1970). Although Fraas (1845, p. ix), who contributed to the exploration of the local flora in the nineteenth century CE, was clearly more skeptical and argued that many plant names of the Greek antiquity had recently been reintroduced into the Greek language to purport a cultural continuity, he admitted that particularly among the names of cultivated plants such with true ancient roots could be found. Hanlidou et al. (2004) showed that a great number of the herbs sold on the market of Thessaloniki today have names which are related to those in Dioscorides.

More difficulties posed those substance names with several possible interpretations. They could be attributed to different material obtained from sometimes taxonomically unrelated species (e.g., trimintína - terebinth resin or crude pine resin, pissa tou xylalá-agar wood, benzoin, or solid storax). Perhaps typical for plant exudates, in many cases the botanical source is not restricted to one single species because the material simply can be collected from several more or less closely related taxa. This appears to be connected with traditional concepts of species demarcations which do not necessarily overlap with those of the Linnean binomial nomenclature. Cases like these can best be comprehended by considering them as plant complexes as suggested by Linares and Bye (1987). A group of different species consisting of one "label" plant and several substitutes share the same name and have common qualities and uses.

Finally, the identification procedure yielded a list of at least 27 different substances (Table 3). With the help of standard texts and additional appropriate references they could be attributed to their respective botanical source. However, in the case of cedar tar and cypress tar the attribution is ambiguous because of the lack of corresponding information in the available references. The 27 substances were obtained from over 43 taxa out of 13 families and included various kinds of resins, gums, tars, and volatile oils. Seven of the resins could be categorized as terpenoid resins obtained from species which are members of the Anacardiaceae, Burseraceae, and Pinaceae. Phenolic resins were only found in the Styracaceae. Various of them were of miscellaneous nature containing substantial portions of both terpenoid and phenolic compounds, belonging to the Altingiaceae, Apicaceae, Cistaceae, and Convolvulaceae. Five of the substances were pure gums belonging to the Rosaceae and Fabaceae. Twelve of the substances were obtained from exotic species originating from Southeast Asia, Middle East, Europe and the neighboring region. The botanical sources of the remaining 15 substances were trees and shrubs which can be found in the Cypriot flora either spontaneously growing or cultivated.

\section{INVENTORY OF RESINS AND GUMS}

The 27 substances were used as ingredients in 118 recipes which corresponded to 224 URs (9.4\% of the total URs in our database; Table 3). Since a recipe may contain more than one plant ingredient and can be indicated for manifold uses the number of URs exceeds the number of recipes. The great majority of the URs concerned medicinal uses, only nine were non-medicinal ones such as the use as paint for church icons or incense. The by far most important use was for dermatological conditions accounting for $35.8 \%$ of all medicinal URs followed by gastrointestinal and hepatic conditions $(18.6 \%)$ and respiratory tract diseases (12.1\%; Figure 2$)$. Of the 26 substances used medicinally 14 were applied both orally and topically, some of them even in a scent remedy, and others either only orally (seven) or topically (five). Altogether nine of them were listed in more than five medicinal recipes.

Of those, mastic is the substance most frequently mentioned, the resin was used as an ingredient in 42 recipes. Conditions distributed over 10 of the 12 UG were identified, in particular dermatological (17 URs), respiratory (16 URs), gastrointestinal and hepatic (14 URs), and ears and eyes (10 URs). Although Pistacia lentiscus is a widespread shrub in the Mediterranean, the main source of supply for commercial mastic has apparently always been the Eastern Aegean island of Chios. Here, the resin is harvested by making incisions to the bark of the small trees of P. lentiscus var. chia (Desf.) Poir. (Flückiger and Hanbury, 1874, pp.142-145; Howes, 1950; Serpico, 2000, p. 434).

Products of pines such as resins, turpentine oil, and wood tar were mentioned in overall 30 recipes. Recipes, which included crude or cooked pine resins were distributed over 7 UGs, above all dermatological complaints (17 URs). Until the early twentieth century the collection of pine resin and the production of tar in particular from Pinus brutia or P. nigra subsp. pallasiana was of some commercial importance in Cyprus (Zeilinger, 1997, p. 140; Tsintides et al., 2002, pp. 77-79; Hadjikyriakou, 2007, pp. 47-49).

Frankincense also called olibanum was mentioned in 28 recipes. The conditions they treated were distributed over 8 UGs and mainly concerned dermatological (20 URs) but also gastrointestinal and hepatic or urogenital uses (each with 6 URs). Southern Arabia and African regions south of Egypt were the main provenances of the oleo gum resin (Serpico, 2000, p. 439). Several Boswellia species of this area produce frankincense, of certain importance are $B$. sacra from southern Oman and Yemen, B. carteri, B. frereana, $B$. bhau-dajiana from Somalia and B. papyrifera from Sudan, Ethiopia, and other places in East Africa (Howes, 1950; Serpico, 2000, pp. 438-439; Langenheim, 2003, p. 363; Blaschek et al., 2007).

Terebinth resin was mentioned in 20 recipes distributed over four medicinal UGs. The majority of the uses concerned dermatological (16 URs) followed by gastrointestinal and hepatic (4 URs) conditions. Blaschek et al. (2007) as earlier Tschirch and Stock (1935/1936, 2.2.1, p. 383) indicate Pistacia terebinthus as the source. In contrary, botanical references on resin producing terebinths from Cyprus mention P. atlantica and not to P. terebinthus (Chrysanthis, 1942; Panaretos, 1967; Tsintides et al., 2002, p. 258; Hadjikyriakou, 2007, pp. 152-155). This inconsistency was highlighted by Meikle (1977/1985, p. 368) and it has been suggested that the confusion owed to variations in past botanical nomenclature considering $P$. atlantica as a variety of P. terebinthus (Mills and White, 1989). In the past, Cyprian turpentine or Cyprus balsam, in fact, had some importance as an item of 


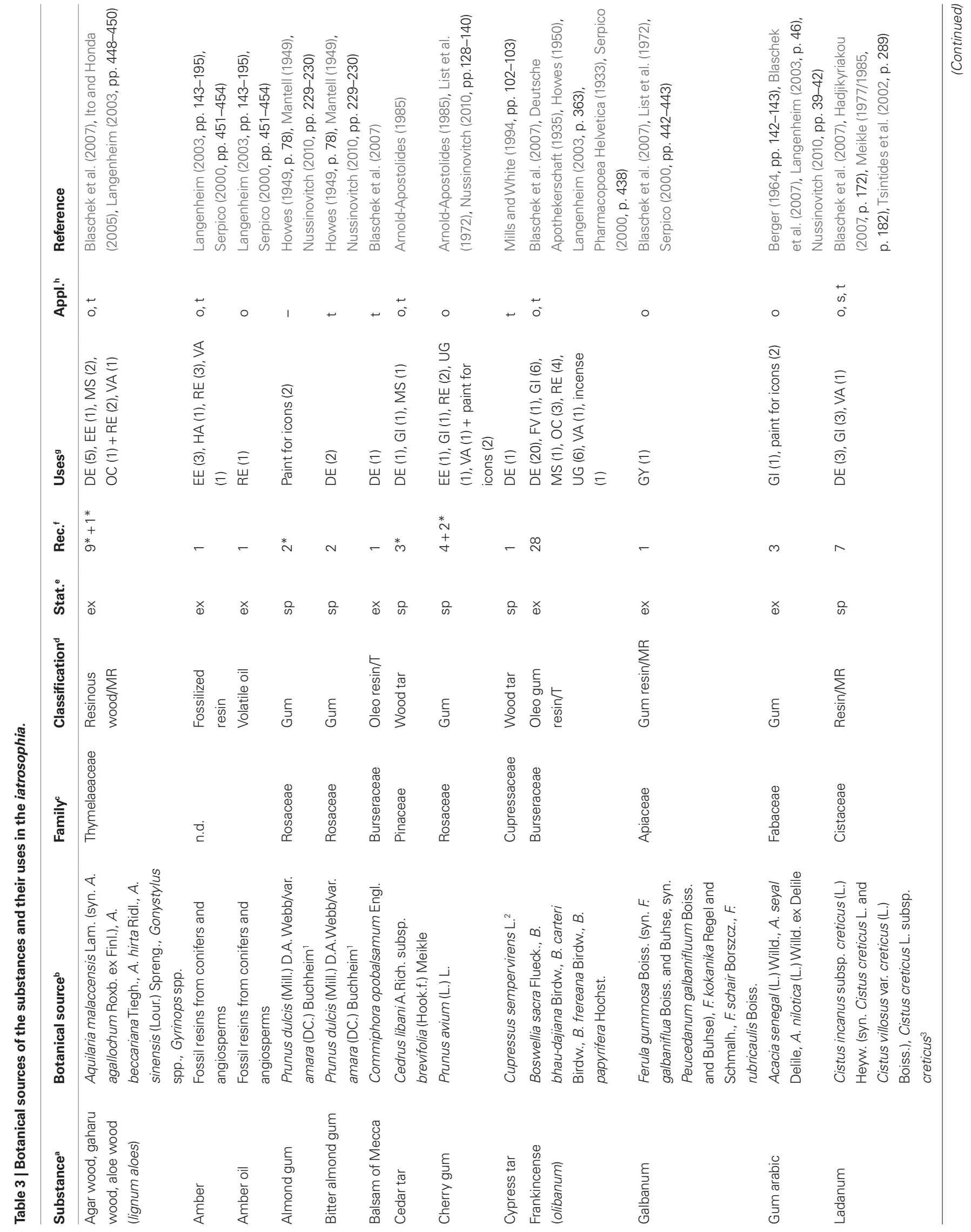




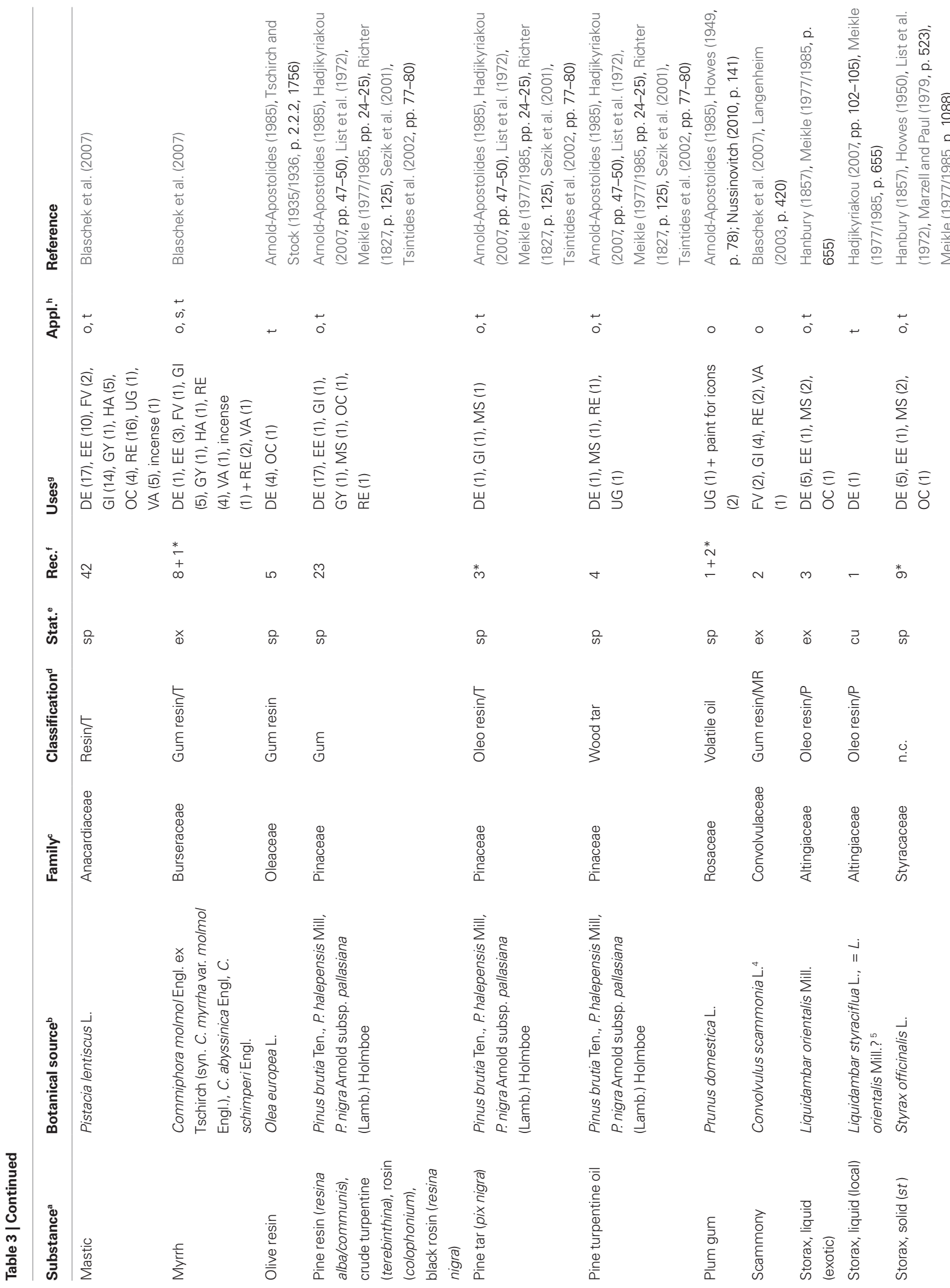




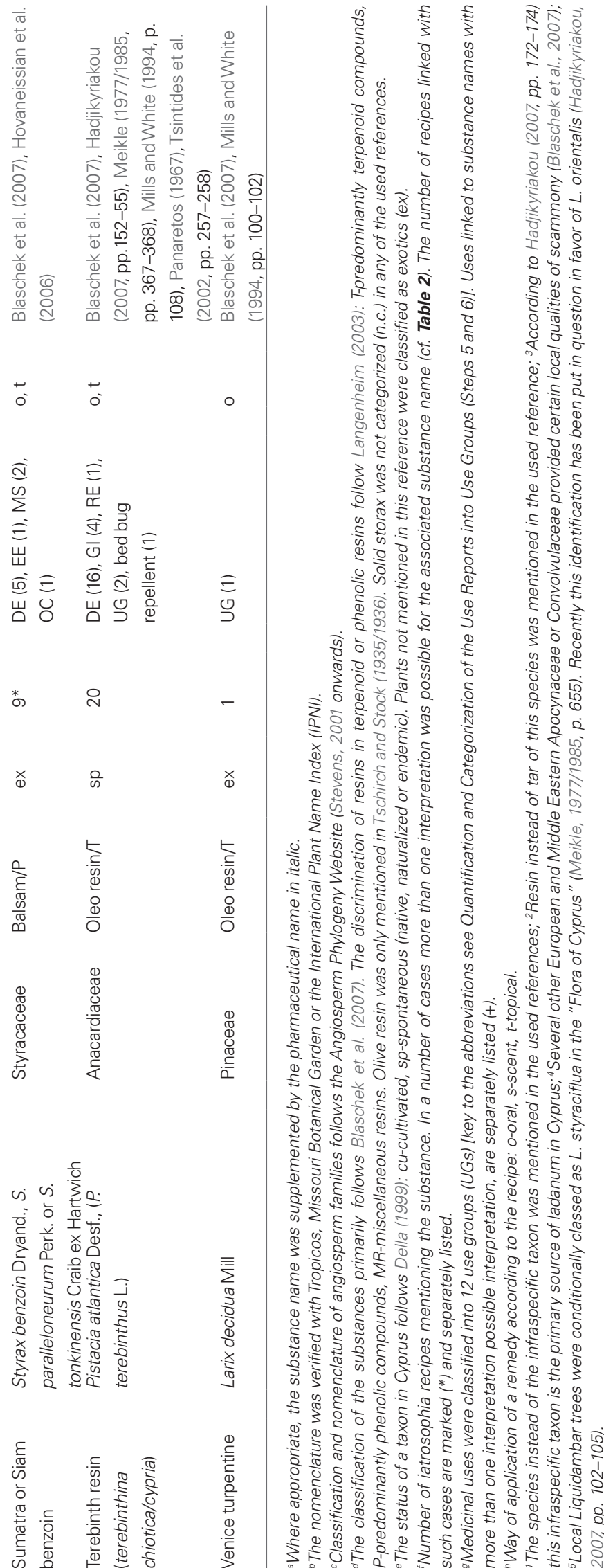

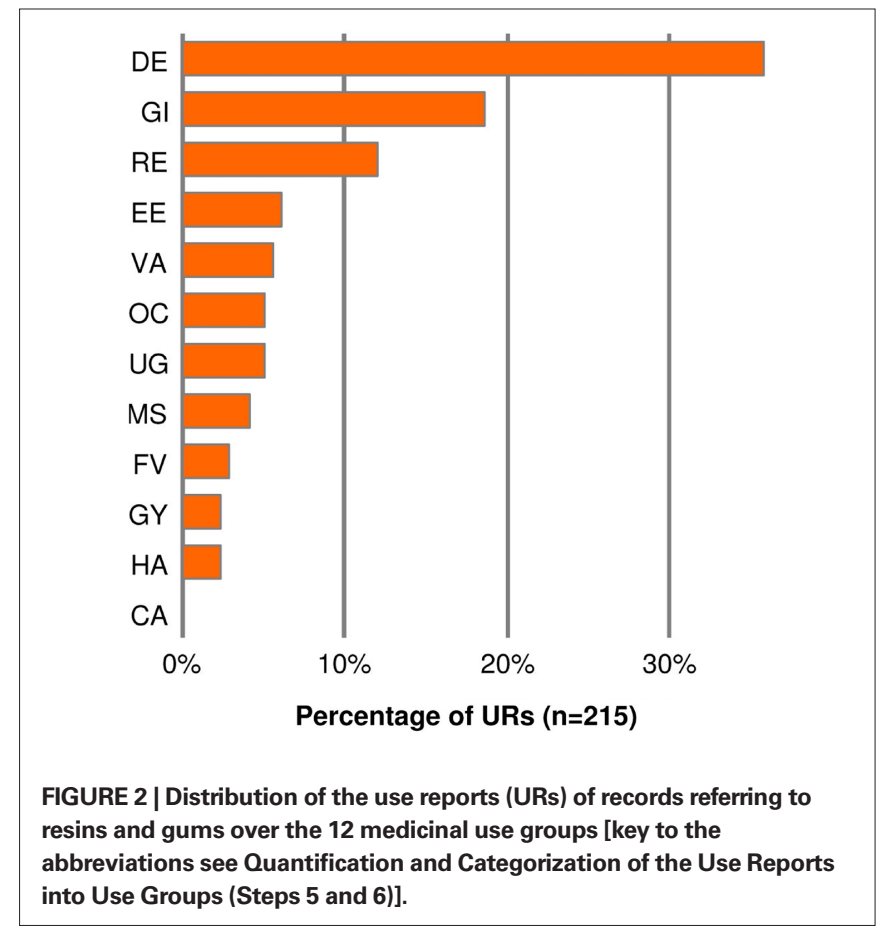

commerce for the island (Thiselton-Dyer, 1885; Tschrich and Stock, $1935 / 1936$, p. 2.2.1,384). Today, specifically in the Pafos area, the resin is still collected to produce a traditional chewing gum called pafitiki píssa (Mills and White, 1989; Hadjikyriakou, 2007, p. 153).

Overall 10 recipes can be associated with agar wood, they treated conditions distributed over 6 UGs. Agar wood is the fragrant resinous wood of trunk and roots from several tropical Thymelaeaceae in particular Aquilaria species of Southeast Asia (Langenheim, 2003, p. 448). As suggested by an account from the fourteenth century, "aloe wood" was actually available in medieval Cyprus (Heyd, 1879, p. 9, 559). Interestingly, agar wood or aloe wood was not referred to by Dioscorides' name agallochōn (Berendes, 1902, 1.21) but by (pissa tou) xylalá, the Cypriot-Greek reproduction of xylaloe (Gennadios, 1914, pp. 2-3) and provides a clue about the origin of this knowledge. Simeon Seth, a Jewish Byzantine doctor of the eleventh century, who played an important role in the transmission of Eastern, in particular Islamic medicine, to the Byzantine Empire, seems to be the first of the Greek writing authors who described the drug in detail by using the name xylaloe (Langkavel, 1866, p. xi 17t; Tschrich and Lippmann, 1933, p. 1348; Varella, 1995).

Nine of the above recipes can also be associated with benzoin or solid storax both obtained from members of the Styracaceae. Two different kinds of benzoin are recognized; Sumatra benzoin from Styrax benzoin and S. paralleloneurum, both found in Indonesia and Malaysia, and Siam benzoin from S. tonkinensis found in Laos, Thailand, Vietnam, and Malaysia or other related species (Blaschek et al., 2007). The first report which unequivocally refers to this resin comes from the fourteenth century Arab traveler Ibn Batuta. It was suggested that the Arabic name luban djawi (frankincense of Java) was later changed to banjawi to finally give benjoin or benzoin (Flückiger and Hanbury, 1874, p. 362; Tschirch and Lippmann, 1933, p. 1383). The only representative 
of the Styracaceae in the Mediterranean and native to Cyprus is Styrax officinalis (Meikle, 1977/1985), the source of solid storax. It should be noted that the substance commonly known by the name storax or styrax today is the exudate from Liquidambar species (see, e.g., Hovaneissian et al., 2006). However, according to Hanbury (1857) the original and classical storax was the "solid storax" produced by $S$. officinalis which in modern times disappeared from commerce and was replaced by the "liquid storax" obtained from Liquidambar orientalis. This view is adhered to in up-to-date standard texts (see, e.g., Blaschek et al., 2007). There is a still ongoing dispute whether S. officinalis does produce a resin at all. In morphological studies of stem samples from trees growing near Izmir (western Turkey) no resin production was observed and, therefore, Zeybek (1971) concluded that plants from this part of Anatolia do not produce it. However, based on reports of resin producing trees in southeastern Turkey, the author underscored the potential importance of geographical varieties. Interestingly, both Dioscorides (Berendes, 1902, 1.79) and Pliny (Bostock and Riley, 1855, p. 12.55) in writing about styrax, mentioned that the product comes from places now in southeastern Turkey, western Syria, or Lebanon but also from Cyprus and Crete. In fact, Hadjikyriakou (2007, p. 229) provided photographic evidence of fresh running resin on a previously injured stem of a living $S$. officinalis tree from a place at the entrance of the Karpas peninsula in northeastern Cyprus.

Myrrh was mentioned in nine recipes including uses distributed over 8 UGs. The majority of them concerned respiratory (6 URs) and gastrointestinal and hepatic conditions (5 URs). The gum resin is collected from several species of the large genus Commiphora, a commonly accepted source is C. molmol (C. myrrha var. molmol; Serpico, 2000, pp. 439-442; Blaschek et al., 2007).

Ladanum was mentioned in seven recipes the uses of which concerned 3 UGs. Both Dioscorides (Berendes, 1902, 1.128) and Pliny (Bostock and Riley, 1855, p. 12.37) stressed that the preferred quality of ladanum comes from Cyprus while the other main provenance was Arabia including the district bordering Syria. Ladanum had been collected and even exported from the island at least until the end of the nineteenth century (Thiselton-Dyer, 1885; Gennadios, 1914; Warren, 2002). Of the four indigenous Cistus species only Cistus incanus subsp. creticus (syn. Cistus creticus and Cistus villosus var. creticus) plays a role as a source of ladanum here, as well as on Crete (Warren, 2002). Hadjikyriakou (2007, pp. 172-174) mentions Cistus creticus L. subsp. creticus as the source of ladanum which in contrary to subsp. eriocephalus (Viv.) Greuter et Burdet, the other local infraspecific taxon, is glandular, strongly resinous and aromatic. In Meikle (1977/1985) the names Cistus creticus L. var. creticus and var. tauricus (Presl) Dunal, respectively, are used.

\section{RELATIONSHIP TO DIOSCORIDES AND WESTERN STANDARD TEXTS}

Conceptually, this comparative analysis joins similar approaches based on retrospective explorations of diachronic data as illustrated by Heinrich et al. (2006). Of specific relevance for the present case are findings suggesting a substantial influence of Dioscorides' De Materia Medica on the development of both the materia medica in European historical texts (De-Vos, 2010) and the orally transmitted popular medicine in regions of the Mediterranean such as
Sardinia, Sicily, and Campania (Italy; Leonti et al., 2009, 2010). The iatrosophia too show remarkable parallels with Dioscorides' text. Roughly two-thirds (18 of 26) of the plant exudates used medicinally here were already listed in this ancient treatise, 16 of them showed some degree of consistency in the UGs and 8 out of these were used to treat conditions of exactly the same UGs. Of all 74 UGs included in the iatrosophia and associated with these 18 substances, 46 UGs $(62.2 \%)$ are also found in De Materia Medica (Table 4). On the other hand changes in terms of numbers and kinds of UGs of substances common to both systems were observed. In particular the only moderate consistency in the UGs of substances which were well known to Dioscorides, some of them originating from the Eastern Mediterranean, such as frankincense, mastic, pine resins, and agar wood or solid storax is notable. While in iatrosophia agar wood, amber, frankincense, and mastic were used in a more diverse way, for almond gum, galbanum, ladanum, and olive resin this was the case in De Materia Medica. In fact, the mean number of UGs treated per substances was even higher in the latter (4.6) than the former (3.6) indicating that in general a substance was used in more diverse ways in De Materia Medica. Analogous results were reported by Leonti (2011) based on a comparison between recent field-based studies from Campania with Matthioli's edition of Dioscorides (Leonti et al. 2010). Those substances not mentioned in Berendes' (1902) translation of Dioscorides concerned tars and volatile oils or resins of local and exotic species (benzoin, balsam of Mecca, liquid storax). They appear to have been introduced in later centuries, some of them perhaps via Islamic medicine as illustrated by the case of benzoin (see Inventory of Resins and Gums). The differences to Dioscorides altogether may be linked to changes in the prevalence of diseases or the influence of other sources.

The comparison to historic pharmaceutical books and modern standard texts of phytotherapy reflects the gradual decline of the use of plant exudates in Western medicine and simultaneously demonstrates the presence of substances in the iatrosophia which have never become established here. While 16 of the 26 substances were mentioned in historic pharmaceutical books only 11 of them remained in the modern standard texts of phytotherapy. Similarly, 14 cases showed some degree of consistency in the UGs between iatrosophia and historic pharmaceutical books, only nine cases did so between iatrosophia and the phytotherapy texts. Of all 65 UGs included in the iatrosophia and associated with the 16 substances used in the historic pharmaceutical books, $41.5 \%$ (27 UGs) are also found in the latter. The analogous percentage of the phytotherapy texts is $34.8 \%$ (16 UGs; based on 46 UGs included in the iatrosophia and associated with 11 substances; Table 4). The mean number of UGs treated per substance was slightly lower than in iatrosophia (3.6), namely 3.0 in the historic pharmaceutical books and 2.5 in the phytotherapy texts. While the highest number of same UGs was found with the uses of myrrh mentioned in the historic pharmaceutical books (five of six UGs), substances with a wide range of indication in iatrosophia such as mastic or frankincense had an overall low degree of consistency $(10-30 \%)$. The general reduction in the use of plant exudates is partly due to the fact that for several reasons in modern phytotherapy old uses were abandoned. A substance may have become obsolete, at least for certain indications or applications, because 
Table 4 | Comparison of the substances and UGs included in the iatrosophia to those of other texts.

\begin{tabular}{|c|c|c|c|c|c|c|c|c|c|c|c|c|c|}
\hline \multirow[b]{2}{*}{ Substances $^{\mathrm{a}}$} & \multirow{2}{*}{$\begin{array}{l}\text { latros. } \\
\text { \#UGs }^{\text {b }}\end{array}$} & \multicolumn{4}{|c|}{ Dioscorides' De Materia Medica } & \multicolumn{4}{|c|}{ Historic pharmaceutical books } & \multicolumn{4}{|c|}{ Modern phytotherapy texts } \\
\hline & & Incl..$^{c}$ & \#UGs & $\begin{array}{l}\text { \#Same } \\
\text { UGs }^{d}\end{array}$ & $\begin{array}{l}\text { \%Same } \\
\text { UGs }^{\mathrm{e}}\end{array}$ & Incl. ${ }^{c}$ & \#UGs ${ }^{\mathbf{b}}$ & $\begin{array}{l}\text { \#Same } \\
\text { UGs }{ }^{d}\end{array}$ & $\begin{array}{l}\text { \%Same } \\
\text { UGs }^{e}\end{array}$ & Incl. ${ }^{c}$ & \#UGs ${ }^{b}$ & $\begin{array}{l}\text { \#Same } \\
\text { UGs }^{d}\end{array}$ & $\begin{array}{l}\text { \%Same } \\
\text { UGs }\end{array}$ \\
\hline Agar wood & 6 & Yes & 3 & 2 & 33.3 & No & 0 & 0 & - & No & 0 & 0 & - \\
\hline Amber & 4 & Yes & 1 & 0 & 0.0 & No & 0 & 0 & - & No & 0 & 0 & - \\
\hline Amber oil & 1 & No & 0 & 0 & - & Yes & 1 & 1 & 100.0 & No & 0 & 0 & - \\
\hline $\begin{array}{l}\text { Bitter almond } \\
\text { gum }\end{array}$ & 1 & Yes & 4 & 1 & 100.0 & No & 0 & 0 & - & No & 0 & 0 & - \\
\hline Cedar tar & 3 & No & 0 & 0 & - & No & 0 & 0 & - & No & 0 & 0 & - \\
\hline Cherry gum & 5 & Yes & 5 & 5 & 100.0 & No & 0 & 0 & - & No & 0 & 0 & - \\
\hline Gum arabic & 1 & Yes & 2 & 1 & 100.0 & Yes & 1 & 0 & 0.0 & Yes & 2 & 1 & 100.0 \\
\hline Ladanum & 3 & Yes & 7 & 3 & 100.0 & Yes & 3 & 2 & 66.7 & No & 0 & 0 & - \\
\hline Mastic & 10 & Yes & 6 & 6 & 60.0 & Yes & 3 & 3 & 30.0 & Yes & 1 & 1 & 10.0 \\
\hline Myrrh & 8 & Yes & 9 & 7 & 87.5 & Yes & 6 & 5 & 62.5 & Yes & 4 & 3 & 37.5 \\
\hline Olive resin & 2 & Yes & 5 & 2 & 100.0 & No & 0 & 0 & - & No & 0 & 0 & - \\
\hline Pine resins & 7 & Yes & 5 & 4 & 57.1 & Yes & 4 & 3 & 42.9 & No & 0 & 0 & - \\
\hline Pine tar & 4 & Yes & 6 & 3 & 75.0 & Yes & 2 & 2 & 50.0 & Yes & 2 & 2 & 50.0 \\
\hline $\begin{array}{l}\text { Pine } \\
\text { turpentine oil }\end{array}$ & 4 & No & 0 & 0 & - & Yes & 7 & 3 & 75.0 & Yes & 2 & 2 & 50.0 \\
\hline Plum gum & 1 & Yes & 2 & 1 & 100.0 & No & 0 & 0 & - & No & 0 & 0 & - \\
\hline $\begin{array}{l}\text { Sumatra/siam } \\
\text { benzoin }\end{array}$ & 4 & No & 0 & 0 & - & Yes & 4 & 1 & 25.0 & Yes & 3 & 2 & 50.0 \\
\hline Terebinth resin & 4 & Yes & 5 & 4 & 100.0 & Yes & 1 & 1 & 25.0 & No & 0 & 0 & - \\
\hline \multirow{2}{*}{$\begin{array}{l}\text { Venice } \\
\text { turpentine }\end{array}$} & 1 & Yes & 1 & 0 & 0.0 & Yes & 1 & 0 & 0.0 & Yes & 3 & 0 & 0.0 \\
\hline & 93 & & 82 & 46 & & & 47 & 27 & & & 28 & 16 & \\
\hline
\end{tabular}

a Substances used medicinally in the iatrosophia.

${ }^{b}$ Total number of use groups (UGs) treated by the medicinal uses of the respective text(s).

Indicates if a substances is included for medicinal purposes in the respective text(s).

${ }^{a}$ Number of UGs included in the iatrosophia which are also found in the respective text(s).

ePercentage of UGs included in the iatrosophia which are also found in the respective text(s).

of toxicological concerns (e.g., oil of turpentine, scammony) or potential allergic reactions (e.g., crude turpentine, colophony; Williamson, 2003; Blaschek et al., 2007). On the other hand new indications of ancient drugs with a long tradition have found their way into modern phytotherapy as illustrated by the gastrointestinal and musculo-sceletal uses of Indian frankincense or the gastrointestinal uses of gum Arabic (Williamson, 2003; Blaschek et al., 2007; ESCOP, 2009).

\section{COMPARISON OF THE SIMPLE REMEDIES TO ETHNOMEDICAL AND BIOACTIVITY DATA}

The great majority of the medicinal URs concerned plant uses listed in compound remedies. Overall 17 simple remedies (14.4\%) were counted, they involved 23 medicinal URs (10.7\%) with 12 different substances. In Table 5 the simple remedies are presented together with their deduced pharmacological functions. The results of the cross-referencing to reported biological activities are shown 
Table 5 | Simple remedies in the iatrosophia: interpretation of the mentioned use and deduced pharmacological functions.

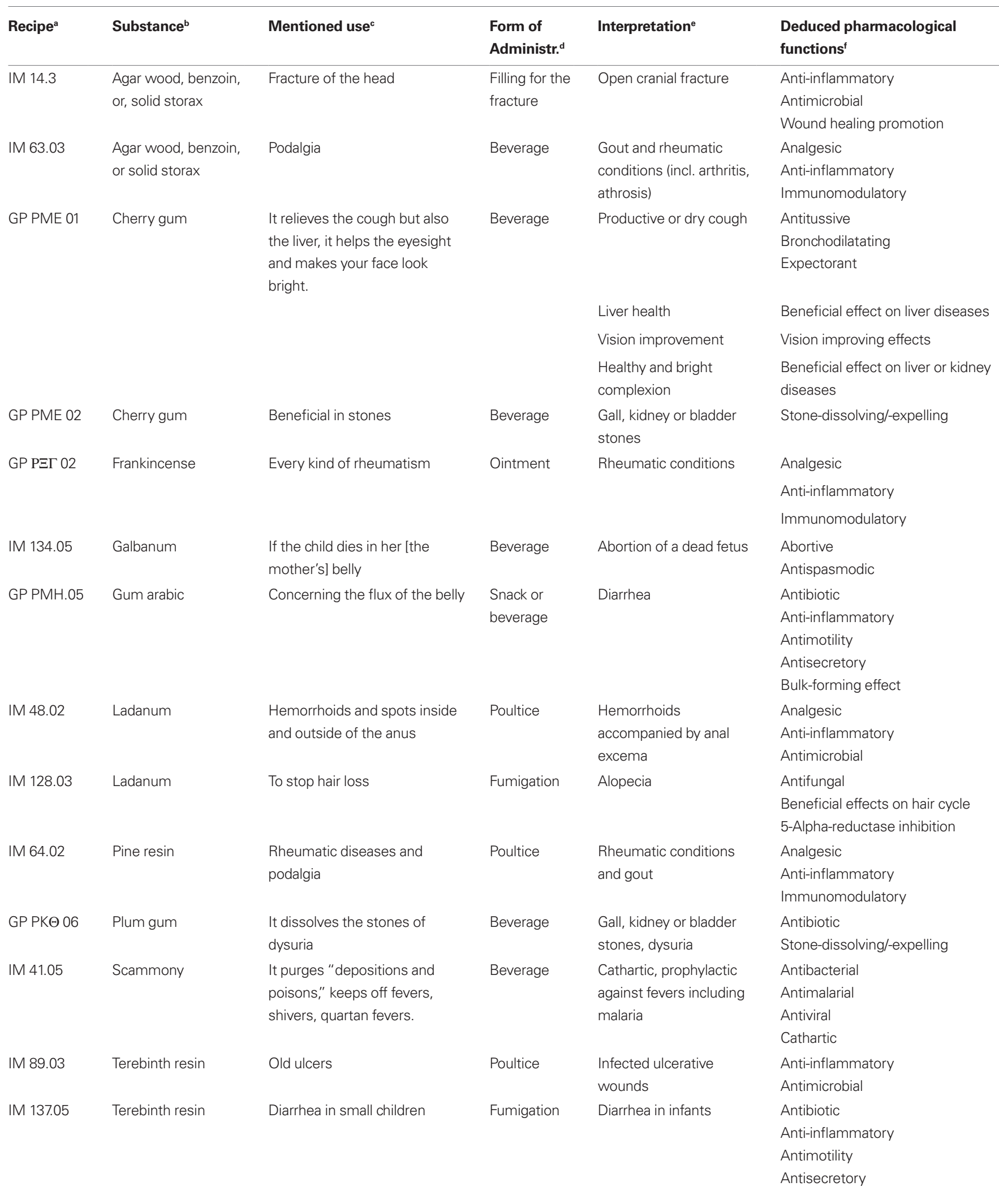


Table 5 | Continued

\begin{tabular}{|c|c|c|c|c|c|}
\hline Recipe $^{a}$ & Substance $^{b}$ & Mentioned use $^{c}$ & $\begin{array}{l}\text { Form of } \\
\text { Administr. }^{d}\end{array}$ & Interpretation ${ }^{\mathrm{e}}$ & $\begin{array}{l}\text { Deduced pharmacological } \\
\text { functions }^{f}\end{array}$ \\
\hline IM 149.03 & Terebinth resin & For those who cannot urinate & Snack & $\begin{array}{l}\text { Impaired urination } \\
\text { possibly related to } \\
\text { bladder stones, urinary } \\
\text { tract infections, BPH or } \\
\text { prostate cancer }\end{array}$ & $\begin{array}{l}\text { Alpha-receptor antagonistic effect } \\
\text { 5-Alpha-reductase inhibition } \\
\text { Antibiotic } \\
\text { Anticancer } \\
\text { Stone-dissolving/-expelling }\end{array}$ \\
\hline KI 9.01 & Terebinth resin & $\begin{array}{l}\text { Deep wounds that need a } \\
\text { filling }\end{array}$ & Ointment & $\begin{array}{l}\text { Incisions caused by } \\
\text { sharp or cutting } \\
\text { implements }\end{array}$ & $\begin{array}{l}\text { Analgesic } \\
\text { Antimicrobial } \\
\text { Wound healing promotion }\end{array}$ \\
\hline KI 10.01 & Terebinth resin & Pestilent ulcers and foul ulcers & Ointment & $\begin{array}{l}\text { Infected ulcerative or } \\
\text { malignant wounds }\end{array}$ & $\begin{array}{l}\text { Anticancer } \\
\text { Anti-inflammatory } \\
\text { Antimicrobial }\end{array}$ \\
\hline
\end{tabular}

a Signature of the recipe, the first two capitals indicate the respective text (see Table 1).

${ }^{b}$ Corresponding to the homonymous column in Table $\mathbf{3}$.

-Uses were translated by retaining the original wording as far as possible.

'Oral applications: beverage, snack; Topical applications: filling, fumigation, ointment, poultice.

e The mentioned uses were interpreted as described in 2.2.1.

${ }^{f}$ The deduction of the pharmacological functions was conducted as described in 2.2.6.

in Table 6. In the following sections for each substance the simple remedies are first compared to relevant ethnomedical data and then the reported biological activities as listed in Table 6 are reviewed. Here, we primarily considered studies that were conducted with the respective substance (including full extracts or fractions). Studies that solely investigated isolated compounds or another plant part of the same or a closely related species were included mainly if no other data were available but then only if they stood in relationship to the respective substance. In Section "Evaluation of the Reported Bioactivity Data" the results of the comparison to the bioactivity data are evaluated.

\section{(i) Agar wood-Aquilaria spp. and other Thymelaeaceae, (ii) benzoin-S. benzoin, $S$. paralleloneurum, $S$. tonkinensis, or (iii) solid storax $-S$. officinalis}

In the third recipe on page 14 of the Iatrosophikon of Mitrophanous (recipe IM 14.03) pounded "píssa tou xylalá" is applied on an open fracture of the cranial bone obviously to protect the injury and promote healing. In IM 63.03 the pounded substance is dissolved in rum and then extracted in the sun for 8 days, the resulting "tincture" is drunk as a remedy against podalgia. The name "píssa tou xylalá" can be attributed to all of the above three substances (i, ii, iii).

(i) Both Dioscorides (Berendes, 1902, 1.21) and Paulus Aegineta (Adams, 1844/1846/1847, 7.3, 18) discussed agar wood by the name of agallochon without, however, mentioning any uses related to the above recipes. In a series of in vitro tests a $70 \%$ ethanolic extract from powdered agar wood of Aquilaria sinensis showed anti-inflammatory properties (Yam, 2007, pp. 81-88). The extract had no inhibitory effect on cyclooxygenase activity but specifically reduced 5 -lipoxygenase activity with an $\mathrm{IC}_{50}$ value around $30 \mu \mathrm{g} / \mathrm{ml}$.

(ii) As in the case of Dioscorides, none of the drugs discussed by Paulus Aegineta seems to refer to benzoin. Today, Sumatra benzoin is known as an ingredient in Friar's Balsam which is used as a vulnerary agent to protect and disinfect the skin (Williamson, 2003). Depending on quality and origin, 70-80\% of Sumatra benzoin consist of free benzoic and cinnamic acids and their corresponding esters. Free benzoic acid (up to 20\%), its esters (70-95\%) and the triterpene $\alpha$-siaresinolic acid (6\%) are the main constituents of Siam benzoin (Blaschek et al., 2007). Benzoic acid is conventionally used as a preservative by the food industry due to its antimicrobial activity. $\mathrm{Mycopol}^{\circledR}$, a preparation containing benzoic acid beside other active compounds has a long history of use in the treatment of fungal skin infections and is beneficial in a large number of patients (Steppert, 1966). Preparations of the balsams from S. benzoin and $S$. tonkinensis were studied for their phagocytotic activity in mice inoculated with E. coli. The 95\% ethanolic extract of the latter species and the insaponifiable fractions of both species showed to protect at least four of five animals $(50 \mathrm{mg} / \mathrm{kg}$, intraperitoneally; Delaveau et al., 1980).

(iii) Although Dioscorides listed various indications for solid storax (Berendes, 1902, 1.79, styrax) and Paulus Aegineta employed it in many remedies (Adams, 1844/1846/1847), no relationship between these ancient uses and those described in the two iatrosophia recipes presented above could be found. Phytochemical or pharmacological properties of solid storax have not been explored so far.

\section{Cherry gum - Prunus avium}

According to recipe PME 01 in the Geoponikon (GP PME 01) drinking every morning cherry gum dissolved in water should relieve cough, improve liver health and vision as well as "make the face look bright." While in GP PME 02 the gum dissolved in wine is recommended in stones. Looking at Dioscorides' account on the gum (Berendes, 1902, 1.157) reveals that the iatrosophia appear to have borrowed from this reference. Paulus Aegineta, too, mentioned the above recipe for stone affections and the gum's ability to ease “asperities of the trachea" (Adams, 1844/1846/1847, 7.3, 167). 
Table 6 | Cross-referencing of deduced pharmacological functions to reported biological activities.

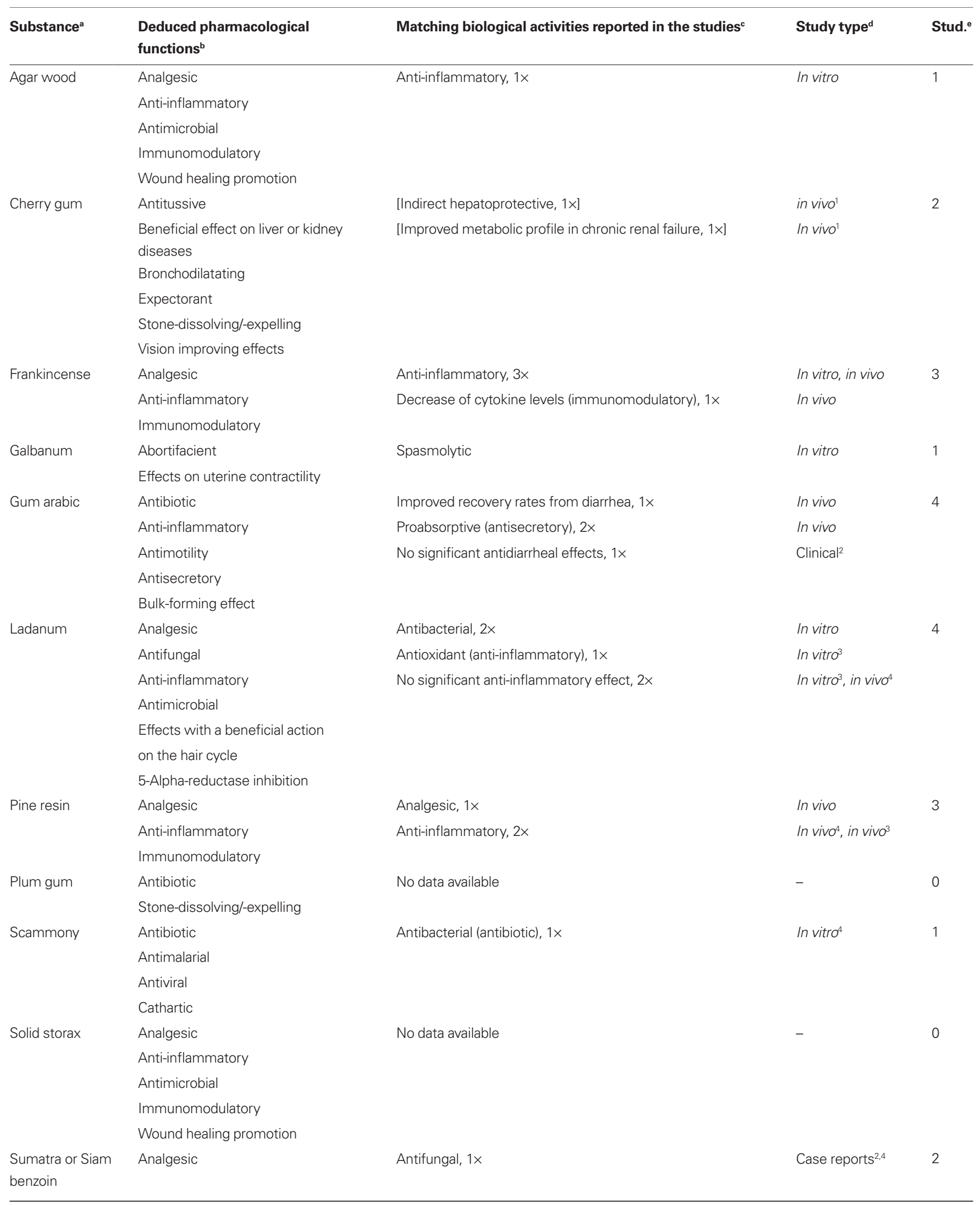


Table 6 | Continued

\begin{tabular}{|c|c|c|c|c|}
\hline Substance $^{a}$ & $\begin{array}{l}\text { Deduced pharmacological } \\
\text { functions }^{b}\end{array}$ & Matching biological activities reported in the studies ${ }^{c}$ & Study type ${ }^{d}$ & Stud. ${ }^{e}$ \\
\hline & Anti-inflammatory & Phagocytotic (antibacterial), $1 \times$ & In vivo & \\
\hline & Antimicrobial & & & \\
\hline & Immunomodulatory & & & \\
\hline & Wound healing promotion & & & \\
\hline \multirow[t]{10}{*}{ Terebinth resin } & Alpha-receptor antagonistic effect & Antibacterial, $1 \times$ & In vitro 4 & 7 \\
\hline & Analgesic & Antimicrobial (antibiotic), $1 \times$ & In vitro & \\
\hline & Antibiotic & Anti-hypernociceptive (analgesic), $1 \times$ & In vivo ${ }^{4}$ & \\
\hline & Anticancer & Anti-inflammatory, $3 \times$ & In vivo ${ }^{4}$, in vivo ${ }^{3}$ & \\
\hline & Anti-inflammatory & Inhibition of LDL oxidation (anti-inflammatory), $1 \times$ & In vitro & \\
\hline & Antimicrobial & Leucotriene inhibition (anti-inflammatory), $1 \times$ & In vitro ${ }^{4}$ & \\
\hline & Antimotility & & & \\
\hline & Antisecretory & & & \\
\hline & Wound healing promotion & & & \\
\hline & 5-Alpha-reductase inhibition & & & \\
\hline
\end{tabular}

${ }^{a}$ Corresponding to the homonymous column in Table 5.

${ }^{b}$ Corresponding to the homonymous column in Table 5. All pharmacological functions referring to the same substance were consolidated.

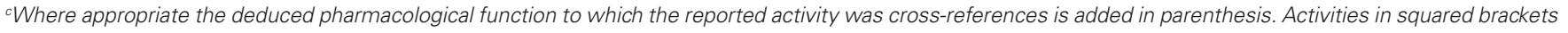

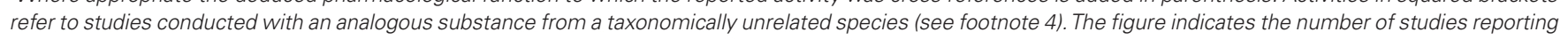
the corresponding activity.

cType of the study reporting the corresponding activity.

${ }^{d}$ Number of studies included in the comparison.

The study was conducted with: ${ }^{1}$ gum arabic, ${ }^{2}$ a compound preparation that included additional further active constituents, ${ }^{3}$ a different plant part, ${ }^{4}$ isolated compounds only.

The symptoms listed in GP PME 01 could be related to a defined disease of some specific organ or, in their entirety, a complex systemic disease or even intoxication. While cherry gum can hardly boast of bioactivity data, another natural gum typically composed of sugar polymers is comparatively well explored. Namely, for gum Arabic a number of the actions have been suggested which are related to some of the pharmacological functions deduced from the above recipes. In Sudan, the gum is prescribed in chronic renal failure (CRF) due to its ability to decrease uremia levels or reduce the frequency of dialysis. In a preliminary study involving 36 CRF patients, a significant improvement of the metabolic profile could be observed in the groups receiving $50 \mathrm{~g}$ gum Arabic daily in comparison to baseline and control (Ali et al., 2008). Although gum Arabic seems to lack a direct hepatoprotective action, $100 \mathrm{mg}$ administered intraperitoneally suppressed macrophage activation and attenuated the extent of liver injury in a rat model of induced hepatic necrosis (Mochida et al., 1996).

\section{Frankincense - Boswellia sacra, B. bhau-dajiana, B. carteri, B. frereana, B. papyrifera}

In recipe GP P $\Xi \Gamma 02$ an ointment containing frankincense, pig fat, and egg white was prepared for the topical treatment of "every kind of rheumatism.” The Roman encyclopedist Celsus (ca. 25 BCE - 50 $\mathrm{CE}$ ), wrote that frankincense was beneficial in the treatment of gout (Martinez et al., 1989) and Paulus Aegineta applied it in a powdermix for the same condition (Adams, 1844/1846/1847, 7.13, 539).

The majority of studies conducted with Boswellia resins refer to Indian frankincense from $B$. serrata, which according to the ESCOP monographis indicated for "relief of painful osteoarthritis" or "treatment of inflammatory bowel disease." Numerous studies have been conducted both with the resin and its constituents, they suggest among others anti-inflammatory and immunomodulatory activities (ESCOP, 2009). Some of these data are based on boswellic acids. These pentacyclic triterpenic acids are characteristic for Boswellia resins including those from African or Arabian species and, therefore, relevant in the context of the above iatrosophia remedy. In fact, studies reviewed by Moussaieff and Mechoulam (2009) showed the potential of these compounds in animal models of arthritic conditions.

However, studies actually conducted with the resin of African or Arabian Boswellia species are limited. One of these studies investigated the anti-inflammatory activity of extract fractions and triterpene acids isolated from the resin of B. carteri in TPA-induced ear edema in mice. Topically applied hexane- and EtOAc-soluble fractions $(1.0 \mathrm{mg} /$ ear $)$ exhibited potent inhibitory activities (91$94 \%$ inhibition, $p<0.01$ significant from control). Isolated diand triterpenes, with the exception of incensole acetate, exhibited marked anti-inflammatory activities ( ID $_{50}$ values of $0.05-0.49 \mathrm{mg} /$ ear). Some of the compounds were equally or more active than the positive controls hydrocortisone ( ID $_{50} 0.03 \mathrm{mg} / \mathrm{ear}$ ) or indomethacine $\left(\mathrm{ID}_{50} 0.3 \mathrm{mg} / \mathrm{ear}\right)$ respectively (Banno et al., 2006). The resin of B. carteri (B. carterii) was also investigated for its potential to influence adjuvant-induced arthritis in rats. The tested acetone extract administered intragastrally at a dose of $0.9 \mathrm{~g} / \mathrm{kg}$ (average body weight: $224.63 \mathrm{~g}$ ) significantly suppressed arthritic scores, attenuated paw edema and decreased cytokine levels (TNF- $\alpha$, IL-1 $\beta$ ), compared to control (Fan et al., 2005). 
In an in vitro model of osteoarthritis, $100 \mu \mathrm{g} / \mathrm{ml}$ of an absolute ethanol extract from the resin of $B$. frereana (the dose was selected as a result of a dose response study on isolated articular chondrocytes) showed a protective effect against cartilage loss by inhibiting breakdown of the collagenous matrix mainly through inhibition of pro-inflammatory mediators (Blain et al., 2010).

\section{Galbanum - Ferula gummosa, F. kokanika, F schair, F. rubricaulis}

According to recipe IM 134.05 drinking pounded galbanum in water will expel a dead embryo/fetus. The same use was mentioned by the authors of "On the Diseases of Women," one of the Hippocratic treatises (Riddle, 1992), by Dioscorides (Berendes, 1902:3.87(97)) as well as by Paulus Aegineta (Adams, 1844/1846/1847, 3.61, 611).

The use of uterine stimulating herbs during pregnancy is regarded as a potential risk factor for a spontaneous abortion (Johns and Sibeko, 2003). Although the ancient use might suggest to place galbanum among these herbs, no studies reporting contractile effects on the uterus are available. Based on its traditional use in the treatment of diarrhea, Sadraei et al. (2001) instead investigated the spasmolytic effects of essential oil and extracts of the gum resin from Ferula gummosa on the contraction of isolated rat ileum. Ether, petrol and methanol extracts inhibited the contractions induced by $80 \mathrm{mM} \mathrm{KCl}$ most potently ( $\mathrm{IC}_{50}$ values: $0.55,1.4$, and $7.5 \mu \mathrm{g} / \mathrm{ml}$, respectively). Etheric or petrolic extracts attenuated the maximum attainable response of $\mathrm{ACh}$ with $\mathrm{IC}_{50}$ values of 10 or $5.1 \mu \mathrm{g} / \mathrm{ml}$, respectively. The authors argued that at least part of the inhibitory effect was due to $\alpha$ - and $\beta$-pinene, two common constituents of the essential oil, ether, and petrol extracts. As shown in a study with the essential oil of Bupleurum fruticosum L., another Apiaceae, fractions containing substantial amounts of these two monoterpenes are able to exert antispasmodic effects on the uterus of the rat (Lorente et al., 1989). While this points to some possibly relevant effects, no direct evidence for the induction of labor or abortion exists for galbanum. Perhaps the iatrosophia use of galbanum should not be linked to a later stage of pregnancy as purported by the wording of the above recipe but rather to earlier stages or fertility control in general. Rosemary (Rosmarinus officinalis L., Lamiaceae), for example, has known antispasmodic in vivo effects on the uterus and is used in tea mixtures for fertility control in Central America (Lemonica et al. (1996).

\section{Gum arabic - Acacia senegal, A. seyal, A. nilotica}

The gum ingested with old wine and some food is said to be a remedy in diarrhea (GP PMH 05). Dioscorides in discussing akakia, used the juice of the pods to "bind a loose belly" and was also acquainted with the astringent properties of the gum (Berendes, 1902, 1.133). Paulus Aegineta was mixing akakia with other herbs for the treatment of dysentery (Adams, 1844/1846/1847, 7.12, 530-531, 534-535). Finally, the gum has been reported as a dysentery remedy from Senegal (Watt and Breyer-Brandwijk, 1962, cited in Maiga et al., 2005).

Published studies on biological effects of the gum have been reviewed in detail by Ali et al. (2009). In particular the effects on the gastrointestinal tract were rated positively; Gum Arabic improved small intestinal absorption of sodium and water in two rat models of induced diarrhea (Wapnir et al., 1997; Codipilly et al., 2006). Other rats recovering from diarrhea induced by cathartic agents gained more weight and had lower fecal output when additionally supplemented with the gum (Teichberg et al., 1999). In general, the in vivo data suggest a potential benefit of gum Arabic in the context of diarrhea and malabsorption caused by infection or intestinal dysfunction.

In a multicenter randomized placebo controlled study 144 boys aged 1-36 months suffering from diarrhea received an oral rehydration solution with or without a mixture containing 9\% gum Arabic in addition to other non-digestible carbohydrates. However, since no significant group differences in stool volume, duration of diarrhea, duration of hospital stay and need of intravenous rehydration could be observed, the mixture was considered ineffective (Hoekstra et al., 2004).

\section{Ladanum - Cistus incanus subsp. creticus}

To heal hemorrhoids accompanied by an anal eczema, $10 \mathrm{dr}$ (drámi) ladanum were heated in $4 \mathrm{dr}$ olive oil, spread on a piece of cloth and applied as a poultice on the affected area. This treatment should be continued for 8 days (IM 48.02). According to recipe IM 128.03 exposing the scalp to smoke of ladanum would stop hair loss. In fact, Ladanum was used to treat hair loss by Dioscorides (Berendes, 1902, 1.128) as well as by Paulus Aegineta (Adams, 1844/1846/1847, $3.1 .5 / 8,339$ and $7.3 .11,208)$. While both of them knew of its applications in liniments or plasters (Adams, 1844/1846/1847, 7.18.8, 578; Berendes, 1902, 1.128), in particular the latter author made specific reference to abscesses, furuncles, or ulcers (Adams, 1844/1846/1847, 4.34.2, 94-95 and 4.39.1, 103). (for synonyms see Inventory of Resins and Gums and Table 3)

While no data are available regarding alopecia, a number of studies investigated potential actions of the Cistus resinor its compounds that could be of relevance in the treatment of hemorrhoids or eczema. Ladanum from C. creticus subsp. creticus exerted only a weak antibacterial activity against Staphylococcus aureus, S. epidermidis, and S. hominis (MIC $2 \mathrm{mg} / \mathrm{ml}$; Demetzos et al., 1999), although its chloroform-methanolic extract showed some inhibitory activity against several bacteria (Acinetobacter anitratus, Enterobacter cloacae, Escherichia coli, Klebsiella pneumoniae, Proteus mirabilis, Pseudomonas aeruginosa, S. aureus; Kalpoutzakis et al., 1998). Isolated sclareol and another labdane type diterpene inhibited the growth of the three tested Staphylococcus germs with a MIC of $0.1 \mathrm{mg} / \mathrm{ml}$ which is 100 -fold lower than streptomycin (Demetzos et al., 1999).

Because ladanum is exuded from the glandular hairs of stem and leaf (Hadjikyriakou, 2007, p. 174), bioactivity data on lipophilic compounds of the leaves or corresponding lipophilic extracts should not be disregarded; Pure ethanolic extracts of $C$. incanus subsp. tauricus and C. aff. creticus at a dose of $10 \mu \mathrm{g} / \mathrm{ml}$ showed an antioxidant effects with TEAC values of 3.6 and 2.5, respectively (Trolox: $\mathrm{IC}_{50}=0.63 \pm 0.02 \mu \mathrm{g} / \mathrm{ml}$ ). However, no significant inhibition of the tested inflammatory parameters (IL-6, IL- $1 \beta$, TNF- $\alpha$, $\mathrm{PGE}_{2}, \mathrm{NF}-\kappa \mathrm{B}$ ) could be shown (Taila et al., 2008). Similarly, in an anti-inflammatory model, no significant effect on the skin barrier repair could be observed with two labdane diterpenes from the leaves of C. creticus subsp. eriocephalus (Viv.) Greuter and Burdet which were applied on the back of hairless mice ( $5 \%$ solution, $25 \mu \mathrm{l} / \mathrm{cm}^{3}$ ) previously exposed to UV-B irradiation (Demetzos et al., 2001). 


\section{Pine resin - Pinus brutia, $\boldsymbol{P}$. halepensis, $\boldsymbol{P}$. nigra subsp. pallasiana}

For the therapy of rheumatic conditions and podalgia a poultice is prepared using pissa mávri (IM 64.2). This name denotes cooked resin known as resina nigra (Table 2), the dark-colored quality of rosin (Richter, 1827). The pounded substance is dissolved in hot barley gruel, the mass is then spread on a piece of cloth of the size of the affected area be it the knee, ankle, or hand. Dioscorides mentioned that one of the properties common to all resins was their warming effect (1.91), in particular "burnt" resin was used in plasters or ointments (1.93; Berendes, 1902). Paulus Aegineta mentioned poultices containing "turpentine" for the treatment of rheumatic diseases and gout (Adams, 1844/1846/1847, 3.78, 663, 665). Arnold-Apostolides (1985) recorded several medicinal uses of topical applications of resin and tar from P. brutia, P. nigra ssp. pallasiana, and P. halepensis from various places in Cyprus. Similar uses and applications were also reported in another ethnobotanical study conducted in western Anatolia (Turkey) for the resin from P. nigra ssp. pallasiana and P. brutia (Honda et al., 1996).

These poultices act as a rubefacients, irritants, and counterirritants. They certainly will achieve an increase of blood flow in the area of application, which may favor the absorption of antiinflammatory secondary metabolites. In this context, an ethyl alcohol extract of turpentine (crude pine resin) from Pinus nigra ssp. pallasiana showed an in vivo anti-nociceptive effect when administered internally thus supporting the existence of such active principles. The extract revealed a dose-dependent analgesic effect in a writhing response in mice induced by acetic acid at a dose of $25 \mathrm{mg} / \mathrm{kg}$. Metamizol at $200 \mathrm{mg} / \mathrm{kg}$ and the resin extract at $50 \mathrm{mg} / \mathrm{kg}$ showed a comparable effect (Gülçin et al., 2003). However, the pharmacological effects of topically applied preparations can only be of any relevance in arthritic inflammations if the active principle is able to penetrate the skin. In fact, certain of the possibly involved compounds show a topical bioavailability and suggest direct anti-inflammatory effects. The diterpene abietic acid, for example, is one of the major compounds in the nonvolatile fraction of the resin of P. brutia (Gören et al., 2010). In a TPA-induced mouse ear edema model topically applied abietic acid inhibited the development of swelling in a significant and dose-dependent manner. The highest dose $(1 \mathrm{mg} /$ ear $)$ showed an inhibitory effect of $74.8 \%$ being in the similar range as the effect of indomethacin $(0.5 \mathrm{mg} /$ ear, inhibitory effect approx. $90 \%$; Fernández et al., 2001).

Another study investigated the in vivo anti-inflammatory activity of an ethyl-acetate extract from the bark of P. brutia in comparison to Pycnogenol ${ }^{\oplus}$, a standardized bark extract of French maritime pine Pinus maritima Lam. In the carrageenan induced rat paw edema model the intraperitoneal administration of each of the preparations inhibited paw-swelling dose-dependently exhibiting significant antiinflammatory activities at doses of 75 and $100 \mathrm{mg} / \mathrm{kg}$. At these doses P. brutia extract also showed a significantly stronger activity than $10 \mathrm{mg} / \mathrm{kg}$ of indomethacin (Ince et al., 2009).

\section{Plum gum - Prunus domestica}

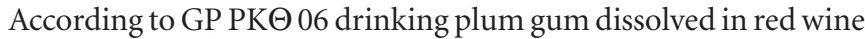
also dissolves the "stones of dysuria." This recipe, obviously related to the doctrine of signatures and an alternative of GP PME 02 (cf. 3.4.2), was already mentioned by Dioscorides (Berendes, 1902, 1.175) and again by Paulus Aegineta (Adams, 1844/1846/1847, 7.3, 180). From the villages of Cyprus plum gum was reported as a tonic, laxative, and vermifuge in substitution of more expensive gums (Arnold-Apostolides, 1985). No bioactivity data were available for this exudate.

\section{Scammony - Convolvulus scammonia}

In IM 41.05 a drink is prepared by mixing $1 / 3 \mathrm{dr}$ scammony and $1 \mathrm{dr}$ of sugar in some water. This remedy would purge easily expelling all "depositions and poisons." Repeating the therapy after 1 month would keep off "fevers, shivers, and quartan fevers" (malaria caused by Plasmodium malariae) for the rest of the year. Although Dioscorides was well acquainted with the purgative effects of scammony [Berendes, 1902, 1.168(171)] and Paulus Aegineta applied the drug in numerous simple and compound remedies for this purpose (Adams, 1844/1846/1847, 7.3,341 and 7.4,481), neither of them mentioned fever or malaria. Unlike these two, the physician Alexander of Tralles from Lydia in Asia Minor, who wrote in the sixth century, highlighted the usefulness of scammony in "quartan" and other fevers linking their cause to excessive "bile and phlegm" (Puschmann, 1878/1879, p. 1.384).

Beside Convolvulus scammonia, several other species of the Apocynaceae and Convolvulaceae provide some sort of scammony, the resinous exudates obtained from the root. Mexican scammony, for example, is obtained from Ipomoea orizabensis (G. Pelletin) Ledeb. ex Steud., Convolvulaceae. This and the former species are recognized to act as laxatives or drastic purgatives due to the resin glycosides present in the exudate (Williamson, 2003; Blaschek et al., 2007). A number of these resin glycosides including scammonins isolated from Ipomoea tricolor and I. orizabensis were tested against different $S$. aureus strains. Synergistic effects between these compounds were observed, revealing direct bactericidal (MIC values $4-32 \mu \mathrm{g} / \mathrm{ml}$ compared to 0.25 and $64 \mu \mathrm{g} / \mathrm{ml}$ for tetracyclin), resistance disabling or antibiotic potentiating effects (Pereda-Miranda et al., 2006). However, studies investigating the potential of scammony or its compounds against malaria causing pathogens (Plasmodium spp.) are lacking.

\section{Terebinth resin - Pistacia atlantica (P. terebinthus)}

In recipes KI 9.01/10.01 and IM 89.03 terebinth resin was pounded, mixed with egg yolk and used as a ointment or applied in a poultice for the treatment of infected, ulcerative, or malignant wounds and deep cuts. To ease urination problems the pounded resin was spread on a piece of bread and eaten (IM 149.03). The latter use could be related to bladder stones, some infection, prostate hyperplasia or cancer. Dioscorides in referring to all resins highlighted their diuretic properties, their use in leprosy or in plasters, poultices, and ointments (Berendes, 1902, 1.91). Paulus of Aegina was making copious use of (rētinēe terebinthinē in topical applications such as plasters or ointments for abscesses, swellings, foul, and spreading ulcers or phagedena (Adams, 1844/1846/1847, 4.41, 4.44, 7.17-7.20). Several references from the Roman Antiquity and the European Renaissance to early modern periods mention the use of the terebinth resin to treat various cancers, tumors, carcinomas and indurations (Hartwell, 1967). Recent accounts on the use of resin from P. atlantica are equally limited as such for P. terebinthus. 
One report from Iraq documents that resin from Pistacia trees (P. atlantica Desf. and P. khinjuk Stocks in Hook.) was applied as an antiseptic to wounds by local inhabitants (Guest and Al-Rawi, 1966, p. 107). Another recipe (IM 137.05) recommends exposing an infant to the smoke of terebinth resin to stop diarrhea. Medicinal smokes are popular in many cultures; the treatment of diarrhea by smoke inhalation has also been reported from Guyana and North America for leaves and stems of two members of the Lauraceae but the understanding of the pharmacodynamics of medicinal smokes is limited (Ben Amar, 2006).

Bioactivity studies investigating the resin of $P$. atlantica are lacking and quantitative analytical data are restricted to the volatile fraction. The crude oleo resin is rich in essential oil, $32.6 \%$ were measured in samples from Morocco with $\alpha$-pinene accounting for 42.9\% (Barrero et al., 2005). Corresponding figures for the variety P. atlantica var. mutica were 22.0 and $70.0 \%$, respectively (Delazar et al., 2004). Different qualities of essential oil of the resin from $P$. atlantica were tested for their antimicrobial potential against seven bacteria (E. coli, E. cloacae, K. pneumoniae, Xanthomonas maltophilia, $P$. aeruginosa, Enterococcus faecalis, S. aureus) and three different strains of C. albicans. The MIC for the Gram-positive and Gramnegative bacteria were $\leq 10$ and $10^{2} \mu \mathrm{g} / \mathrm{ml}$, respectively, and for $C$. albicans between $10^{3}$ and $1 \mathrm{mg} / \mathrm{ml}$ (Benabderrahmane et al., 2009).

Alpha-pinene isolated from the turpentine oil of Pinus pinaster Aiton exhibited a distinctive bioactivity against various isolates of Actinomadura madurae with MICs ranging between 3.3 and $5.0 \mu \mathrm{l} / \mathrm{ml}$ (positive control streptomycin: $29.8-50.0 \mu \mathrm{l} / \mathrm{ml}$ ) and a minimum microbicidal concentration (MMC) of $10.0 \mu \mathrm{l} / \mathrm{ml}$ (streptomycin: $50.0-75.0 \mu \mathrm{l} / \mathrm{ml}$ ). This pathogen is the main cause of actinomycetoma, an infectious skin disease which is able to eventually form a tumor and cause problematic secondary infections (Stojkovic et al., 2008). The same monoterpene compound isolated from the essential oil of Ugni myricoides (Kunth) O. Berg, Myrtaceae, was investigated for its anti-hypernociceptive potential in a model of neuropathic pain of the sciatic nerve in mice. Alphapinene orally applied at doses of 25 and $50 \mathrm{mg} / \mathrm{kg}$ was capable of abolishing the hypernociceptive response with inhibitions of 64 and $89 \%$, respectively. This effect was comparable to gabapentin, a drug clinically used to treat neuropathic pain $(70 \mathrm{mg} / \mathrm{kg}$, orally applied: inhibition of 88\%; Quintão et al., 2010).

The potential of resin extracts from $P$. terebinthus L. var. chia to protect LDL from oxidation was dependent on the polarity of the solvent and ranged between 27.0 and $49.5 \%$. A corresponding extract from Chios mastic gum ( $P$. lentiscus L. var. chia) showed a distinctly higher protection rate sometimes more than doubling the one achieved with the terebinth resin (Andrikopoulos et al., 2003).

Anti-inflammatory and anti-phospholipase $\mathrm{A}_{2}$ activities of a methanolic extract from $P$. terebinthus L. galls were investigated in a number of animal models. In TPA- or EEP-induced mouse ear edema models topically applied extract $(1 \mathrm{mg} / \mathrm{ear})$ revealed a 58 or $44 \%$, respectively, inhibition of chronic inflammatory swelling. Orally applied extract $(200 \mathrm{mg} / \mathrm{kg})$ inhibited paw edema induced by PLA from two different types of venoms by 48-67\% (GinerLarza et al., 2000). In partially identical mouse models the same group tested four different triterpenes from $P$. terebinthus L. galls administered in concentrations between 0.3 and $1 \mathrm{mg} / \mathrm{kg}$ topically and $30 \mathrm{mg} / \mathrm{kg}$ intraperitoneally (Giner-Larza et al., 2001 and 2002).
Two isoforms, masticadienonic acid and masticadienolic acid, were also found in turpentine resin (Blaschek et al., 2007). They both showed significant inhibitory activities in ear and paw edemas. The latter additionally inhibited leukotriene $\mathrm{B}_{4}$ production in rat polymorphonuclear leukocytes with an $\mathrm{IC}_{50}$ of $16.6 \mu \mathrm{M}$ (apigenin $\mathrm{IC}_{50}$ of $13 \mu \mathrm{M}$; Giner-Larza et al., 2002).

\section{Evaluation of the reported bioactivity data}

Altogether 28 studies were included in this comparison (Table 6). Although several further studies were found in the literature search, the unusual high concentrations of the test samples applied in the respective assays eventually questioned the significance of the suggested biological activities and made us abstain from including them. Similar observations were made by Adams et al. (2009) when discussing the results of bioscientific studies in relationship to the uses described in the European Renaissance herbals. This problem was addressed by Gertsch (2009) in a commentary regarding the interpretation of molecular pharmacological data in ethnopharmacological publications. The author argued that much of the problem is related to a misemployment of the concentration-effect paradigm and the overinterpretation of in vitro data.

The comparison of the deduced pharmacological functions with matching biological activities reported in the literature revealed an overall fragmentary picture in terms of the available data (Table 6). While for cherry gum (Prunus avium) no matching data were found, plum gum (Prunus domestica), solid storax (S. officinalis) and, apart from its essential oil, terebinth resin from $P$. atlantica do not appear to have been explored at all. For the remaining 9 of the 12 substances, which to a certain extent have been the subject of medicinal or pharmacological research, one or more studies were available that reported some sort of matching effects. Frankincese, gum Arabic and pine resin had corresponding bioactivity data for at least half of the deduced pharmacological functions. The majority of the associated data were linked to studies including mainly in vitro (11) and animal models (14) only two studies included data from patients. In several of these models, however, isolated compounds, extracts from other plant parts or compound preparations and not the substance mixture were tested. Some of the studies referring to gum Arabic, ladanum, and turpentine resin also reported inactivity, weak, or non-significant effects. Nevertheless, in the great majority of the cases the available studies reported positive results. At least four cases have appropriate data available which allows to draw direct conclusions on the putative pharmacological effectiveness of the respective substance, because the associated in vivo studies were actually conducted with the plant exudate or its full extract and showed meaningful results; For the iatrosophia use of pine resin in rheumatic conditions and podalgia corresponding evidence is available demonstrating the analgesic potential of a crude resin extract from P. nigra subsp. pallasiana. Moreover, both from other historical texts as well as ethnobotanical studies various topical applications of pine resins were reported. Overlapping uses with ethnobotanical data "can lend strength and credibility to a lead which originated from a historical text” (Hunt, 1996, p. 92). Ethnomedical uses supporting the findings of animal studies were reported too for applications of gum Arabic as a diarrhea remedy, frankincense from Boswellia carteri in the treatment of rheumatic diseases and Sumatra or Siam benzoin as an antiseptic agent. 


\section{CONCLUSIONS}

Firstly, this study provides a systematic ethnopharmacological approach to analyze largely unedited historical texts and highlights some conceptual issues and specific challenges inherent to such a work. The integration of a diachronic aspect in the identification procedure of the substance names allowed us to show a remarkable continuity of the nomenclature in several cases. Such an approach can also provide important clues about the point of time a drug or its use had been introduced, its origin or the trade routes involved.

The comparison based on the number of UGs in common demonstrates parallels with Dioscorides' De Materia Medica in roughly two-thirds of the investigated substances and within those in again roughly two-thirds of the concerned UGs. On the other hand it points to the presence of a relevant share of knowledge not connected with this ancient treatise. This is particularly notable when considering the importance plant exudates already played in antiquity, the comprehensiveness of De Materia Medica and the pronounced relationship of this text to the Eastern Mediterranean. When speaking about plant habitats Dioscorides most frequently made references to places in Asia Minor (Turkey), on the Greek mainland, in Egypt and Syria (Riddle, 1985, p. 3). Moreover, Dioscorides' text must have been readily available to Byzantine medical writers, without the need of translations. The reliance on the plant lore of earlier written sources is one of the main characteristics of the Byzantine materia medica (Stannard, 1984, p. 205). Taken together, one would expect an even greater influence of Dioscorides on the iatrosophia than the one observed in this study. In this context, the non-Dioscoridean influence suggests a complex pattern of knowledge exchange. Overall, this resulted in an integration of knowledge from so far poorly understood sources.
The application of ethnopharmacological concepts in the analysis of the simple remedies provides rational criteria to estimate the potential therapeutic effectiveness of the plant uses. In the majority of the cases where relevant bioactivity data were available we found a confirmation pointing to the putative validity of many of the other not yet investigated plant uses in the iatrosophia. Numerous remedies are labeled as "tried and tested successfully" by their authors and underscore the practical nature of this knowledge. One can assume that many of these remedies have repeatedly undergone selection based on their perceived safety, tolerability and effectiveness. Perhaps they are best described as the distillate of what was found best and most useful from preceding sources, like, for example, remedies of Byzantine medicine in general (Bennett, 2000). Therefore, the iatrosophia are a rewarding tool to inspire the development of herbal drugs based on multicomponent extracts but also phytochemical or pharmacological research. If integrated in models for studying the development of herbal medicines in the (Eastern) Mediterranean or Europe these texts offer unique scientific insight.

\section{ACKNOWLEDGMENT}

We would like to thank Dr. Kyriaki Zannettou-Pandeli (Larnaca), Dr. Andreas P. Georgiades (Nicosia) and Kostis Kokkinoftas (Kykkos Monastery Research Centre, Nicosia) for discussions about specific aspects of iatrosophia texts from Cyprus as well as to all the nuns and monks of those monasteries participating in the field-based part of the project and which also provided relevant information on the present topic. Thanks also to the A. G. Leventis Foundation for the grant which supported a substantial part of this research project.

\section{REFERENCES}

Adams, M., Alther, W., Kessler, M., Kluge, M., and Hamburger, M. (2011). Malaria in the Renaissance: remedies from European herbals from the 16th and 17th century. J. Ethnopharmacol. 133, 278-288.

Adams, M., Berset, C., Kessler, M., and Hamburger, M. (2009). Medicinal herbs for the treatment of rheumatic disorders-a survey of European herbals from the 16th and 17th century. $J$. Ethnopharmacol. 121, 343-359.

Adams, F. (1844/1846/1847). The Seven Books of Paulus Aegineta. In three volumes. Translated from the Greek. With a commentary embracing the complete knowledge produced by the Greeks, Romans and Arabians on all subjects connected with medicine and surgery. London: Sydenham Society. Digital text, Bibliothèque Interuniversitaire de Medicine et d'Odontologie, Paris. Available at: http://web2.bium.univparis5.fr [last accessed 12/11/2010].

Ali, A. A., Ali, K. E., Fadlalla, A. E., and Khalid, K. E. (2008). The effects of gum arabic oral treatment on the metabolic profile of chronic renal failure patients under regular haemodialysis in Central Sudan. Nat. Prod. Res. 22, 12-21.

Ali, B. H., Ziada, A., and Blunden, G. (2009). Biological effects of gum arabic: a review of some recent research. Food Chem. Toxicol. 47, 1-8.

Aliotta, G., Piomelli, D., Pollio, A., and Touwaide, A. (2003). Le piante medicinali del Corpus Hippocraticum. Milano, Napoli: Angelo Guerini \& Associati; Istituto italiano per gli studi filosofici.

Andrikopoulos, N. K., Kaliora, A. C., Assimopoulou, A. N., and Papapeorgiou, V. P. (2003). Biological activity of some naturally occurring resins, gums and pigments against in vitro LDL oxidation. Phytother. Res. 17, 501-507.

Arnold-Apostolides, N. (1985). Contribution à la connaissance ethnobotanique et médicinale de la flore de Chypre. Ph.D. thesis, Faculté de sciences pharmacologiques et biologiques, Université René Descartes de Paris, Luxembourg.

Banno, N., Akihisa, T., Yasukawa, K., Tokuda, H., Tabata, K., Nakamura, Y. Nishimura, R., Kimura, Y., and Suzuki, T. (2006).Anti-inflammatory activities of the triterpene acids from the resin of Boswellia carteri. J. Ethnopharmacol. 107, 249-253.

Barrero, A. H. M., Arteaga, J., Akssira, M., Mellouki, F., Belgarrabe, A., and Blaquez, M. (2005). Chemical composition of the essential oils of Pistacia atlantica Desf. J. Essent. Oil Res. 17, 52-54.

Ben Amar, M. (2006). Cannabinoids in medicine: a review of their therapeutic potential. J. Ethnopharmacol. 105 $1-25$.

Benabderrahmane, M., Benali, M. Aouissat, H., and Jordan Bueso, M.-J. (2009). Activite antimicrobienne des huiles essentielles de Pistacia atlantica Desf. de l'Algerie. Phytothérapie 7, 304-308.

Bennett, D. (2000). Medical practice in manuscripts in Byzantium. Soc. Hist. Med. 13, 279-291.

Berendes, J. (1902). Des Pendanius Dioscorides aus Anazarbos Arzneimittellehre in fünf Büchern. Stuttgart: Ferdinand Enke. Digital edition, Heilpflanzen-Welt, Bibliothek. Multi MED vision GbR Berliner Medizinredaktion, Medizin und Medien. Available at: http://buecher.heilpflanzen-welt. de/Dioskurides-Arzneimittellehre/ (accessed January 21, 2011).

Berger, F. (1964). Handbuch der Drogenkunde. Band VI. Balsame, Harze, Gummiharze, Gummi, Milchsäfte und Extrakte. Wien: Wilhelm Maudrich.

BGA (1978-1994). German Commission E Monographs. Bundes-Anzeiger, Bundesgesundheitsamt. Digital edition, Heilpflanzen-Welt, Bibliothek. Multi MED vision GbR Berliner Medizinredaktion, Medizin und Medien. Available at: http:// buecher.heilpflanzen-welt.de/ BGA-Commission-E-Monographs/ [accessed January 21, 2011].

Blain, E. J., Ali, A. Y., and Duance, V. C. (2010). Boswellia frereana (frankincense) suppresses cytokine-induced matrix metalloproteinase expression and production of pro-inflammatory molecules in articular cartilage. Phytother. Res. 24, 905-912.

Blaschek, W., Ebel, S., Hackenthal, E. Holzgrabe, U., Keller, K., Reichling, J., and Schulz., and V. (2007). Hagers Enzyklopädie der Arzneistoffe und Drogen. Sechste (neu bearbeitete 
und ergänzte) Auflage. Stuttgart: Wissenschaftliche Verlagsgesellschaft and Springer.

Bloch, I. (1902). "Byzantinische Medizin," in Handbuch der Geschichte der Medizin, eds. T. Puschmann, M. Neuburger, and J.Pagel (Jena: Fischer), 492-513.

Boer, E., and Ella, A. B. (2000). Plant Resources of South-East Asia. Leiden: Backhuys Publishers.

Bostock, J., and Riley, H. (1855). The Natural History. Pliny the Elder. London: Taylor and Francis. Digital edition, Perseus Digital Library Project, ed. G. R. Crane. Tufts University, Boston and Medford. Available at: http://www.perseus. tufts.edu/ [accessed January 14, 2011].

Bradley, P. (1992). British Herbal Compendium, Vol. 1. Bournemouth: British Herbal Medicine Association.

Bruce, M. (1970). John Sibthorp. Taxon $19,353-362$.

Bruneton, J. (1995). Pharmacognosy, Phytochemistry, Medicinal Plants. Hampshire: Intercept.

Brunton, L. L., Goodman, L. S., and Gilman, A. (2006). Goodman of Gilman's the pharmacological basis of therapeutics, 11th Edn. New York: McGraw-Hill.

Buenz, E. J., Bauer, B. A., Johnson, H. E., Tavana, G., Beekman, E. M., Frank, K. L., and Howe, C. L. (2006). Searching historical herbal texts for potential new drugs. BMJ 333, 1314-1315.

Buenz, E. J., Johnson, H. E., Beekman, E. M., Motley, T. J., and Bauer, B. A. (2005). Bioprospecting Rumphius's Ambonese Herbal: Volume I. J. Ethnopharmacol. 96, 57-70.

Buenz, E. J., Schnepple, D. J., Bauer, B. A., Elkin, P. L., Riddle, J.M., and Motley, T. J. (2004). Techniques: Bioprospecting historical herbal texts by hunting for new leads in old tomes. Trends Pharmacol. Sci. 25, 494-498.

Chrysanthis, K. (1940). Theriaka tis Kyprou. Kypriakai Spoudai. 39-63.

Chrysanthis, K. (1944). Ta aitia ton noson kata tous Kyprious. Kypriakai Spoudai H 83-97.

Chrysanthis, K. (1951). Ena kypriako iatrosophi. Kypriakai Spoudai IE, $\gamma^{\prime}-1 \delta$ '.

Chrysanthis, K. (1966). Ena karamanlidiko kypriako iatrosophi. Kypriakai Spoudai 185-189.

Chrysanthis, K. (1988). Dimodis iatrikitis Kyprou symmeikta. Lefkosia (Nicosia): Iatrikou Syllogou Ippokratis.

Chrysanthis, K. (1942, ed. 1991). "Kypriakes farmakeftikes yles sto "peri ylis iatrikis" tou Dioskouridi," in Apo tin istoria tis kypriakis iatrikis, ed. K. Chrysanthis (Nicosia: Politistikou Kentrou tis Laïkis Trapezas), 43-56.
Clark, P.A. (2002).Landscape, Memories, and Medicine: Traditional Healing in Amari, Crete. J. Mod. Greek Stud. 20, 339-365.

Codipilly, C. N., Teichberg, S., and Wapnir, R.A. (2006). Enhancement of Absorption by gum arabic in a model of gastrointestinal dysfunction. J. Am. Coll. Nutr. 25, 307-312.

Cordell, G. A., and Colvard, M. D. (2005). Some thoughts on the future of ethnopharmacology. J. Ethnopharmacol. 100, 5-14.

Council of the Pharmaceutical Society of Great Britain (1911). The British Pharmaceutical Codex. An Imperial Dispensatory for the use of Medical Practitioners and Pharmacists. London: The Pharmaceutical Press. Digital edition, ed. H. Kress (20012011), Henriette's Herbal Homepage. Available at: http://www.henriettesherbal.com/ [accessed February 13, 2011].

Cox, P.A. (1998). The promise of Gerard's Herball: new drugs from old books. Endeavour 22, 51-53.

Dawkins, R. M. (1936). The Semantics of Greek Names for Plants. J. Hellenic Stud. 56, 1-11.

Delaveau, P., Lallouette, P., and Tessier, A. M. (1980). Drogues végétales stimulant l'activité phagocytaire du système réticulo-endothélial. Planta Med. 40, 49-54.

Delazar, A., Reid, R. G., and Sarker, S. D. (2004). GC-MS analysis of the essential oil from the oleoresin of Pistacia atlantica var. mutica. Chem. Nat. Comp. 40, 24-27.

Della, A. (1999). The Cyprus Flora: in Checklist Format. Nicosia: International Plant Genetic Resources Institute \& Agricultural Research Institute, Ministry of Agriculture, Natural Resources and Environment. Demetzos, C., Dimas, K., Hatziantoniou, S., Anastasaki, T., and Angelopoulou, D. (2001). Cytotoxic and antiinflammatory activity of labdane and cis-clerodane type diterpenes. Planta Med. 67, 614-618.

Demetzos, C., Stahl, B., Anastassaki, T., Gazouli, M., Tzouvelekis, L. S., and Rallis, M. (1999). Chemical analysis and antimicrobial activity of the resin Ladano, of its essential oil and of the isolated compounds. Planta Med. 65, 76-78.

De-Vos, P. (2010). European materia medica in historical texts: longevity of a tradition and implications for future use. J. Ethnopharmacol. 132, 28-47.

Deutsche Apothekerschaft (1935, ed. 1953). Ergänzungsbuch zum Deutschen Arzneibuch, Erg. B. 6. 6. Ausgabe. Stuttgart: Deutscher Apotheker-Verlag.
Dietel, M., Dudenhausen Joachim W., and Suttorp, N. (2003). Harrisons Innere Medizin (English title: Harrison's principles of internal medicine). Berlin: ABW Wissenschaftsverlag.

ESCOP. (2009). ESCOP Monographs, Supplement to the 2nd Edn. Exeter: European Scientific Commitee on Phytotherapy.

Fan, A. Y., Lao, L., Zhang, R. X., Zhou, A. N., Wang, L. B., Moudgil, K. D., Lee, D. Y., Ma, Z. Z., Zhang, W. Y., and Berman, B. M. (2005). Effects of an acetone extract of Boswellia carterii Birdw. (Burseraceae) gum resin on adjuvant-induced arthritis in lewis rats. J. Ethnopharmacol. 101, 104-109.

Fernández, M. A., Tornos, M. P., García, M. D., De-las-Heras, B., Villar, A. M., and Sáenz, M. T. (2001). Antiinflammatory activity of abietic acid, a diterpene isolated from Pimenta racemosa var. grissea. J. Pharm. Pharmacol. $53,867-872$.

Filaretos. (1924-1925). Iatrosophikon, synachthen ypo tou skevophylakos tisen Kypro Ieras Monis Machaira, Mitrophanous 1790-1867. Lefkosia (Nicosia): Ekdosis Ieras Monis Machaira.

Fiore, C., Eisenhut, M., Ragazzi, E., Zanchin, G., and Armanini, D. (2005) A history of the therapeutic use of liquorice in Europe. J. Ethnopharmacol. 99, 317-324.

Flückiger, F. A., and Hanbury, D. (1874). Pharmacographia, A History of the Principal Drugs of Vegetable Origin met within Great Britain and British India. London: Macmillan and Co.

Fraas, C. (1845). Synopsis Plantarum Florae Classicae. München. E. A. Fleischmann.

Gennadios, P. G. (1914). Lexikon Phytologikon. Athens: Paraskeva Leoni.

Georgiadis, A. P. (1995). I istoria tis trelas stin Kypro kata tin tourkokratia kai anglokratia. Lefkosia (Nicosia): Private publication.

Gertsch, J. (2009). How scientific is the science in ethnopharmacology? Historical perspectives and epistemological problems. J. Ethnopharmacol. 122, 177-183.

Giner-Larza, E. M., Máñez, S., Giner, R. M., Recio, M. C., Prieto, J. M., CerdáNicolás, M., and Ríos, J. L. (2002) Anti-inflammatory triterpenes from Pistacia terebinthus galls. Planta Med. 68, 311-315.

Giner-Larza, E.M.,Máñez,S., Giner-Pons, R. M., Carmen Recio, M., and Ríos, J. L. (2000). On the anti-inflammatory and anti-phospholipase $\mathrm{A}(2)$ activity of extracts from lanostane-rich species. J. Ethnopharmacol. 73, 61-69.

Giner-Larza, E. M., Máñez, S., Recio, M. C., Giner, R. M., Prieto, J. M., Cerdá-
Nicolás, M., and Ríos, J. L. (2001). Oleanonic acid, a 3-oxotriterpene from Pistacia, inhibits leukotriene synthesis and has anti-inflammatory activity. Eur. J. Pharmacol. 428, 137-143.

Gonzalez-Tejero, M. R., Casares-Porcel, M., Sanchez-Rojas, C. P., RamiroGutierrez, J. M., Molero-Mesa, J., Pieroni, A., Giusti, M. E., Censorii, E., de Pasquale, C., Della, A., ParaskevaHadijchambi, D., Hadjichambis, A., Houmani, Z., El-Demerdash, M., El-Zayat, M., Hmamouchi, M., and Eljohrig, S. (2008). Medicinal plants in the Mediterranean area: synthesis of the results of the project Rubia. $J$. Ethnopharmacol. 116, 341-357.

Gören, A. C., Bilsel, G., Oztürk, A. H., and Topçu, G. (2010). Chemical composition of natural colophony from Pinus brutia and comparison with synthetic colophony. Nat. Prod. Commun. 5, 1729-1732.

Guest, E., and Al-Rawi, A. (1966). Flora of Iraq. Volume 1. Introduction to the Flora. Baghdad: Ministry of Agriculture of the Republic of Iraq.

Gülçin, I., Büyükokuroglu, M. E., Oktay, M., and Küfrevioglu, O. I. (2003). Antioxidant and analgesic activities of turpentine of Pinus nigra Arn. subsp. pallsiana (Lamb.) Holmboe. J. Ethnopharmacol. 86, 51-58.

Hadjichambis, A. Ch., ParaskevaHadjichambi, D., Della, A., Giusti, M. E., de Pasquale, C., Lenzarini, C., Censorii, E., Gonzales-Tejero, M. R., Sanchez-Rojas, C. P., RamiroGutierrez, J. M., Skoula, M., Johnson, C., Sarpaki, A., Hmamouchi, M., Jorhi, S., El-Demerdash, M., El-Zayat, M., and Pieroni, A. (2008). Wild and semidomesticated food plant consumption in seven circum-Mediterranean areas. Int. J. Food Sci. Nutr. 59, 383-414.

Hadjiioannou, K. (2000). Etymologiko lexiko tis omiloumenis kypriakis dialektou. Lefkosia (Nicosia): Tamasos. Ekdosi 2.

Hadjikyriakou, G. N. (2007). Aromatika kai artymatika fyta stin Kypro. Lefkosia (Nicosia): Politistiko Idryma Trapesis Kyprou.

Hanbury, D. (1857). On Storax. Science Papers, Chiefly Pharmacological and Botanical. 129-150.

Hanlidou, E., Karousou, R., Kleftoyanni, V., and Kokkini, S. (2004). The herbal market of Thessaloniki (N Greece) and its relation to the ethnobotanical tradition. J. Ethnopharmacol. 91, 281-299.

Hartwell, J. L. (1967). Plants used against cancer. A survey. Acanthaceae to Anacardiaceae. Lloydia 30, 379-405.

Heiberg, J. (1921/1924). Paulus Aegineta, 2 volumes. Corpus medicorum 
Graecorum 9.1 \& 9.2. Leipzig: Teubner. Digital edition, TLG ${ }^{\circledR}$ (Thesaurus Linguae Graecae), University of California, Irvine. Available at: http:// www.tlg.uci.edu/ [accessed January 16, 2011].

Heinrich, M., Kufer, J., Leonti, M., and Pardo-de-Santayana, M. (2006). Ethnobotany and ethnopharmacology - interdisciplinary links with the historical sciences. J. Ethnopharmacol. 107, 157-160.

Hepper, F. N. (1987). Trees and shrubs yielding gums and resins in the ancient Near East. Bull. Sumer. Agri.3, 107-114.

Heyd, W. (1879). Geschichte des Levantehandels im Mittelalter, Band 2. B) Alter südlicher Warenzug aus dem Orient ans Mittelmeer. Stuttgart: J.G. Cotta'schen Buchhandlung.

Hoekstra, J. H., Szajewska, H., Zikri, M. A., Micetic-Turk, D., Weizman, Z., Papadopoulou, A., Guarino, A., Dias, J. A., and Oostvogels, B. (2004). Oral rehydration solution containing a mixture of non-digestible carbohydrates in the treatment of acute diarrhea: a multicenter randomized placebo controlled study on behalf of the ESPGHAN working group on intestinal infections. J. Pediatr. Gastroenterol. Nutr. 39, 239-245.

Höfler, M. (1899). Deutsches Krankheitsnamen-Buch. München: Piloty \& Loehle. Digital copy, Google books. Available at: http://books.google. com [accessed December 16, 2010]

Holland, B. K. (1994). Prospecting for drugs in ancient texts. Nature 369 , 702 .

Honda, G., Yeșilada, E., Tabata, M., Sezik, E., Fujita, T., Takeda, Y., Takaishi, Y., and Tanaka, T. (1996). Traditional medicine in Turkey. VI. Folk medicine in west Anatolia: Afyon, Kütahya, Denizli, Muǧla, Aydin provinces. $J$. Ethnopharmacol. 53, 75-87.

Hovaneissian, M., Archier, P., Mathe, C., and Vieillescazes, C. (2006). Contribution de la chimie analytique à l'étude des exsudats végétaux styrax, storax et benjoin. C. R. Chimie 9 , 1192-1202.

Howes, F. N. (1949). Vegetable Gums and Resins. Waltham: Chronica Botanica Company.

Howes, F. N. (1950). Age-old resins of the Mediterranean region and their uses. Econ. Bot. 4, 307-316.

Hunt, T. (1996). "From plant lore to pharmacy: a prototype of the process," in Prospecting for drugs in ancient and medieval European texts: A scientific approach, ed. B. K. Holland (Amsterdam: Harwood Academic Publishers GmbH), 91-96.

Ince, I., Yesil-Celiktas, O., KarabayYavasoglu, N. U., and Elgin, G. (2009).
Effects of Pinus brutia bark extract and Pycnogenol in a rat model of carrageenan induced inflammation. Phytomedicine 16, 1101-1104.

Ito, M., and Honda, G. (2005). Taxonomical identification of agarwood-producing species. Nat. Med. 59, 104-112.

Johns, T., and Sibeko, L. (2003). Pregnancy outcomes in women using herbal therapies. Birth Defects Res. B Dev. Reprod. Toxicol. 68, 501-504.

Kalpoutzakis, E., Chinou, I., Mitaku, S., Skaltsounis, A., and Harvala, C. (1998). Antibacterial labdane-type diterpenes from the resin "ladano" of Cistus creticus subsp. creticus. Nat. Prod. Lett. 11, 173-179.

Karageorghis, V. (1996). "Some aspects of the maritime trade of Cyprus during the late Bronze age," in The development of the Cypriot economy, From the prehistoric period to the present day, eds V. Karageorghis and D. Michaelides (Nicosia: University of Cyprus \& Bank of Cyprus), 61-67.

Kargotis, G. (1951). Dyo cherografa tis en Kypro Ieras Monis tis Panagias Machaira. Kypriakai Spoudai IE, $\mu \zeta$-oๆ.

Kostoula, D. D. (1991). Agapios Landos, Geoponikon, Venetia 1643. Volos: Tinos.

Koureas, N. (2006). "I iatriki stin Kypro kata to mesaiona," in H Iatriki stin Kypro - Apo tin Archaiotita mechri tin Anexartisia, ed. H. VryonidouYiangou (Nicosia: Politistiko Kentrou Omilou Laïkis), 101-149.

Kufer, J., Förther, H., Pöll, E., and Heinrich, M. (2005). Historical and modern medicinal plant uses - the example of the Ch'orti' Maya and Ladinos in Eastern Guatemala. J. Pharm. Pharmacol. 57, 1127-1152.

Kyprianou, C. S. (1987). Ergasies tou Kyprou Chrysanthi ston tomea tis laikis iatrikis. Laografiki Kyprou41-64.

Kyriazis. (1926). Kypriaka Chronika. Larnaka: Cheimonidi.

Langenheim, J. H. (2003). Plant resins. Chemistry, Evolution, Ecology, and Ethnobotany. Portland: Timber Press.

Langkavel, B. (1866, reprint 1964). Botanik der späteren Griechen. Amsterdam: Adolf M. Hakkert.

Lardos, A. (2006). The botanical materia medica of the Iatrosophikon -a collection of prescriptions from a monastery in Cyprus. J. Ethnopharmacol. 104, 387-406.

Lemonica, I., Damasceno, D., and di-Stasi L. C. (1996). Study of the embryotoxic effects of an extract of rosemary (Rosmarinus officinalis L.). Brazil. J. Med. Biol. Res. 29, 223-227.

Lentini, A. (2004). "Fragrant substances and therapeutic compounds," in Pyrgos-Mavroraki, Advanced Technology in Bronze Age Cyprus, ed. M. R. Belgiorno (Nicosia: Archaeological Museum), 45-47.

Leonti, M. (2011). The future is written Impact of scripts on the cognition, selection, knowledge and transmission of medicinal plant use and its implications for ethnobotany and ethnopharmacology. J. Ethnopharmacol. 134, 542-555.

Leonti, M., Cabras, S., Weckerle, C. S. Solinas, M. N., and Casu, L. (2010). The causal dependence of present plant knowledge on herbals Contemporary medicinal plant use in Campania (Italy) compared to Matthioli (1568). J. Ethnopharmacol. 130, 379-391.

Leonti, M., Casu, L., Sanna, F., and Bonsignore, L. (2009). A comparison of medicinal plant use in Sardinia and Sicily-De Materia Medica revisited? J. Ethnopharmacol. 121, 255-267.

Lev, E. (2002). Reconstructed materia medica of the Medieval and Ottoman al-Sham. J. Ethnopharmacol. 80, 167-179.

Lev, E., and Amar, Z. (2002). Ethnopharmacological survey of traditional drugs sold in the Kingdom of Jordan. J. Ethnopharmacol. 82, 131-145.

Lev, E., and Amar, Z. (2008). Practical materia medica of the medieval Eastern Mediterranean according to the Cairo Genizah. Leiden: Brill.

Linares, E., and Bye, R. A. (1987). A study of four medicinal plant complexes of Mexico and adjacent United States. J. Ethnopharmacol. 19, 153-183.

List, P.H., Hörhammer, L., Kern, W., Roth H. J., and Schmid, W. (1972). Hagers Handbuch der Pharmazeutischen Praxis. Vollständige (4.) Neuausgabe. Berlin, Heidelberg, New York: Springer.

López-Muñoz, F., Alamo, C., and GarcíaGarcía, P. (2006). "The herbs that have the property of healing...," the phytotherapy in Don Quixote. $J$. Ethnopharmacol. 106, 429-441.

Lorente, I., Ocete, M. A., Zarzuelo, A. Cabo, M. M., and Jimenez, J. (1989). Bioactivity of the essential oil of Bupleurum fruticosum. J. Nat. Prod. 52, 267-272.

Maiga, A., Diallo, D., Fane, S., Sanogo, R., Paulsen, B. S., and Cisse, B. (2005) A survey of toxic plants on the market in the district of Bamako, Mali: traditional knowledge compared with a literature search of modern pharmacology and toxicology. $J$. Ethnopharmacol. 96, 183-193.

Mantell, C. L. (1949). The water-soluble gums - their botany, sources and utilization. Econ. Bot. 3, 1-31.
Marangou, A. G., and Georgiadis, A. P. (2006). "I iatriki stin Kypro kata ti diarkeia tis anglokratias," in H Iatriki stin Kypro - Apo tin Archaiotita mechri tin Anexartisia, ed. H. VryonidouYiangou (Nicosia: Politistiko Kentrou Omilou Laikis), 217-398.

Martinez, D., Lohs, K., and Janzen, J. (1989). Weihrauch und Myrrhe. Kulturgeschichte und wirtschaftliche Bedeutung. Botanik - Chemie Medizin. Stuttgart: Wissenschaftliche Verlagsgesellschaft.

Marzell, H., and Paul, H. (1979). Wörterbuch der deutschen Pflanzenamen. Vierter Band. Sabadilla-Zygophyllum. Stuttgart und Wiesbaden: S. Hirzel und Franz Steiner.

Meikle, R. (1977 and 1985). Flora of Cyprus, Vol. 1 and 2. Kew: The Bentham-Moxon Trust, Royal Botanical Gardens.

Mills, J., and White, R. (1989). The identity of the resins from the Late Bronze Age shipwreck at Ulu Burun (Kaş). Archaeometry 31, 37-44.

Mills, J., and White, R. (1994). The Organic Chemistry Of Museum Objects. Oxford: Butterworth-Heinemann.

Mochida,S., Ohno, A.,Arai, M., Tamatani, T., Miyasaka, M., and Fujiwara, K. (1996). Role of adhesion molecules in the development of massive hepatic necrosis in rats. Hepatology 23, 320-328.

Moussaieff, A., and Mechoulam, R. (2009). Boswellia resin: from religious ceremonies to medical uses; a review of in-vitro, in-vivo and clinical trials. J. Pharm. Pharmacol. 61, 1281-1293.

Myrianthopoulos, K. I. (1925). "Erymineftikos pinax tou iatrosophikou Machaira," in Iatrosophikon, synachthen ypo tou skevophylakos tis en Kypro Ieras Monis Machaira, Mitrophanous 1790-1867, ed. Filaretos (Nicosia: Ekdosis Ieras Monis Machaira), 165-191.

Nebel, S., Pieroni, A., and Heinrich, M. (2006). Ta chòrta: wild edible greens used in the Graecanic area in Calabria, Southern Italy. Appetite 47, 333-342.

Nussinovitch, A. (2010). Plant gum exudates of the world. Boca Raton: CRC Press, Taylor \& Francis Group.

Ölker, P., and Direkçi, B. (2009). Mehmed Nidâî's Verse Medicine Treatise, Keyf-i Kıtab-1 Nıda1. Selçuk Üniversitesi Sosyal Bilimler Enstitüsü Dergisi 22, 295-305.

Panaretos, A. (1967). I chlorida tou topou mas. Nicosia: Pankyprios Enosis Geoponon, Pankyprios Enosis Geoponon.

Panaretos, A. (1979). I pissa tis Pafou. Laografiki Kypros 26, 53-54. 
Papangellou, R. (2001). To kypriako idioma. Athens: Iolkos, Ekdosi A.

Pardo-de-Santayana, M., Tardío, M., Heinrich, M., Touwaide, A., and Morales, R. (2006). Plants in the works of Cervantes. Econ. Bot. 60, 159-181.

Pereda-Miranda, R., Kaatz, G. W., and Gibbons, S. (2006). Polyacylated oligosaccharides from medicinal Mexican morning glory species as antibacterials and inhibitors of multidrug resistance in Staphylococcus aureus. J. Nat. Prod. 69, 406-409.

Petridis, G. (2000). Ta laografika. Lemesos (Limassol): Private publication.

Pharmacopoea Helvetica. (1933). Editio Quinta. Bern: Stämpfli \& Cie.

Piomelli, D., and Pollio, A. (1994). Medicinal plants. Nature 371, 9.

Pollio, A., Natale, A. de, Appetiti, E., Aliotta, G., and Touwaide, A. (2008). Continuity and change in the Mediterranean medical tradition: Ruta spp. (rutaceae) in Hippocratic medicine and present practices. $J$. Ethnopharmacol. 116, 469-482.

Puschmann, T. (1878-1879). Alexander von Tralles. Original-Text und Übersetzung. Wien: Braumüller. Digital copy, Google books. Available at: http://book.google.com [accessed November 21, 2010].

Quintão, N. L., Da-Silva, G. F., Antonialli, C. S., Rocha, L. W., Cechinel-Filho, V., Cicció, J. F. (2010). Chemical composition and evaluation of the antihypernociceptive effect of the essential oil extracted from the leaves of Ugni myricoides on inflammatory and neuropathic models of pain in mice. Planta Med. 76, 1411-1418.

Raven, J., Lindsell, A., and Raven, F. (2000). Plants and Plant Lore in Ancient Greece. Oxford: Leopard's Head.

Remington, J. P., Woods, H. C. (1918). The Dispensatory of the United States of America, Botanicals Only, 20th Edn. Digital edition, ed. M. Moore (20032011), Henriette's Herbal Homepage. Available at: http://www.henriettesherbal.com/ [accessed February 13, 2011].

Richter, G. A. (1827). Ausführliche Arzneimittellehre. Handbuch für praktische Ärzte. Zweiter Band. Berlin: August Rücker.

Riddle, J. M. (1985). Dioscorides on Pharmacy and Medicine. Austin: Univ. of Texas Press.

Riddle, J. M. (1987). Recognition of Drugs in Classical Antiquity. Wisconsin: American Institute of the History of Pharmacy.

Riddle, J. M. (1992). Contraception and abortion from the ancient world to the Renaissance. Cambridge, MA: Harvard University Press.
Riddle, J. M. (1996). “The medicines of Greco-Roman antiquity as a source of medicines for today," in Prospecting for Drugs in Ancient and Medieval European Texts: A Scientific Approach, ed. B. K. Holland (Amsterdam: Harwood Academic Publishers), 7-17.

Riddle, J. M. (2002). "History as a tool in identifying "new" old drugs," in Flavonoids in Cell Function, ed. B. S. Buslig (New York: Kluwer Academic/ Plenum), 89-95.

Sadraei,H.,Asghari, G. R., Hajhashemi, V., Kolagar, A., and Ebrahimi, M. (2001). Spasmolytic activity of essential oi and various extracts of Ferula gummosa Boiss. on ileum contractions. Phytomedicine 8, 370-376.

Scarborough, J. (1984). "Early Byzantine pharmacology," in Symposium on Byzantine Medicine. Dumbarton Oaks Papers, Number Thirty-Eight, ed. J. Scarborough (Washington, DC: Dumbarton Oaks Research Library and Collection), 213-232.

Serpico, M. (2000). "Resins, amber and bitumen," in Ancient Egyptian Materials and Technology, ed. P. T. Nicholson (Cambridge: Cambridge University Press), 432-474.

Sezik, E., Yeşilada, E., Honda, G. Takaishi, Y., Takeda, Y., and Tanaka, T. (2001). Traditional medicine in Turkey X. Folk medicine in Central Anatolia. J. Ethnopharmacol. 75, 95-115.

Spanopoulos, G. I. (1935). I laiki iatrikien Kypro. Nicosia: Chr. Nikolaos.

Stannard, J. (1984). “Aspects of Byzantine materia medica," in Symposium on Byzantine Medicine. Dumbarton Oaks Papers, Number Thirty-Eight, ed. J. Scarborough (Washington DC: Dumbarton Oaks Research Library and Collection), 205-211.

Stavridis, T. (2006). "I Iatriki stin Kypro kata tin Othomaniki Periodo," in H Iatriki stin Kypro - Apo tin Archaiotita mechri tin Anexartisia, ed. H. Vryonidou-Yiangou (Nicosia: Politistiko Kentrou Omilou Laïkis), 150-215.

Steppert, A. (1966). Die Therapie von Hautkrankheiten mit Mycopol. Wien. Med. Wochenschr. 116, 307-309.

Stevens, P. (2001). Angiosperm Phylogeny Website. Version 9, June 2008 (and more or less continuously updated since). Available at: http://www. mobot.org/MOBOT/research/ APweb/ [accessed November 06, 2010].

Stojkovic, D., Sokovicz, M., Glamoclija, J., Dzamic, A., Ristic, M., Fahal, A., Khalid, S., Djuic, I., and Petrovic, S. (2008). Suseceptibility of three clinical isolates of Actinomodura madurae to $\alpha$-pinene, the bioactive agent of Pinus pinaster turpentine oil. Arch. Biol. Sci. Belgrade 60, 697-701.

Taila, S, Fiebich, B.L., Efferth, T., Beckwith, C., Prieto, J., and Heinrich, M. (2008) Anti-inflammatory and anti-oxidant activity of six Cistus species. J Pharm. Pharmacol. 60, A-62-A-63.

Teichberg, S., Wingertzahn, M.A., Moyse, J., and Wapnir, R. A. (1999). Effect of gum arabic in an oral rehydration solution on recovery from diarrhea in rats. J. Ped. Gastroenterol. Nutr. 29, 411-417.

Thiselton-Dyer, W. (1885). Notes on Cyprian drugs. Pharm. J. Trans. 3rd Series 15, 385-386.

Touwaide, A. (1992). "The corpus of greek medical manuscripts: a computerized inventory and catalogue," in Tradizione e ecdotica dei test medici tardo-antichi e bizantini. Atti de Convegno internazionale, Anacapri, 29-31 ottobre 1990, ed. A. Garzya (Binghamton: The Harworth Press), 75-92.

Touwaide, A. (2007). "Byzantine hospital manuals (iatrosophia) as a source for the study of therapeutics," in The Medieval Hospital and Medical Practice, ed. B. S. Bowers (Aldershot: Ashgate), 147-174.

Tschirch, A., and Stock, E. (1935/1936) Die Harze. Dritte und überarbeitete Auflage von "Die Harze und die Harzbehälter”. II. Band. Berlin: Gebrüder Bornträger.

Tschrich, A., and Lippmann, E. (1933) Allgemeine Phamakognosie. Dritte Abteilung. Leipzig: Bernhard Tauchnitz.

Tsintides, T., Hadjikyriakou, G. N., and Christodoulou, C.S. (2002). Trees and shrubs in Cyprus. Nicosia: Foundation Anastasios G. Leventis, Cyprus Forest Association.

Varella, E. A. (1995). Orientalische Elemente in der byzantinischen Heilkunde. Medicina nei Secoli. Arte e Scienza 7, 29-40.

Varella,E.A. (1999). La thérapeutique byzantine dans le monde grec d'epoque ottomane. Medicina nei Secoli. Arte e Scienza 11, 577-584.

Velephantou, K. (1913, ed. 1978). To Kyprianarion. Athens: Dyonisos.

Viney, D. (1994). An Illustrated Flora of North Cyprus. Koenigstein: Koeltz Scientific Books.

Wapnir, R. A., Wingertzahn, M. A. Moyse, J., and Teichber, S. (1997). Gum arabic promotes rat jejunal sodium and water absorption from oral rehydration solutions in two models of diarrhea. Gastroenterology 112, 1979-1985.
Warren, P. M. (2002). "Cistus creticus L.," in Sema Menelaou Parlama, eds T. Detorakis and A. Kalokairinos (Heraklion: Society for Cretan Historical Studies), 243-265.

Watt, J. M., and Breyer-Brandwijk, M. G. (1962). Medicinal and poisonous plants of South Africa, 2nd Edn. Edinburgh: E. and S. Livingstone Ltd.

Wellmann, M. (1906/1907/1914 (repr. 1958)). Pedanii Dioscuridis Anazarbe de materia medica libri quinque, 3 volumes. Berlin: Weidmann. Digital edition, TLG ${ }^{\circledR}$ (Thesaurus Linguae Graecae), University of California, Irvine. Available at: http://www.tlg uci.edu/ [accessed January 16, 2011].

Williamson, E. (2003). Potter's Herbal Cyclopaedia. Saffron Walden: The C.W. Daniel Company Limited.

Wolff-Berlin, H. (1928). "Die natürlichen Harze," in Monographien aus dem Gebiete der Fett-Chemie, ed. K. H. Bauer (Stuttgart: Wissenschaftliche Verlagsgesellschaft), 1-372.

Yam, J. (2007). The search for bioactive compounds in tropical plants to target hormone imbalance associated diseases. Ph.D. thesis, Basel: University of Basel, Faculty of Science.

Zeilinger, J. (1997). Cypern, Orient und Okzident. München: Matthes \& Seitz.

Zeybek, N. (1971). Liefert Styrax officinalis L. ein Harz? Bulletin de la Société Botanique Suisse 80, 189-193.

Zisper, B. (2009). John The Physician's Therapeutics. A Medical Handbook in Vernacular Greek. Leiden, Boston: Brill.

Conflict of Interest Statement: The authors declare that the research was conducted in the absence of any commercial or financial relationships that could be construed as a potential conflict of interest.

Received: 01 April 2011; paper pending published: 28 April 2011; accepted: 15 June 2011; published online: 01 July 2011.

Citation: Lardos A, Prieto-Garcia I and Heinrich M (2011) Resins and gums in historical iatrosophia texts from Cyprus a botanical and medico-pharmacological approach. Front. Pharmacol. 2:32. doi: 10.3389/fphar.2011.00032

This article was submitted to Frontiers in Ethnopharmacology, a specialty of Frontier in Pharmacology.

Copyright (C) 2011 Lardos, Prieto-Garcia and Heinrich. This is an open-access article subject to a non-exclusive license between the authors and Frontiers Media SA, which permits use, distribution and reproduction in other forums, provided the original authors and source are credited and other Frontiers conditions are complied with. 